Revised text-R1

\title{
Origin and Significance of Olistostromes in the Evolution of Orogenic Belts: A Global Synthesis
}

\section{Corresponding author:}

Dr Andrea Festa

Email: andrea.festa@unito.it

Andrea Festa

Dipartimento di Scienze della Terra, Università di Torino, 10125 Torino, Italy

\section{Kei Ogata}

Dipartimento di Fisica e Scienze della Terra "Macedonio Melloni", Università degli Studi di Parma, I43124 Parma, Italy

\section{Gian Andrea Pini}

Dipartimento di Matematica e Geoscienze, Università di Trieste, 34128 Trieste, Italy

\section{Yildirim Dilek}

Department of Geology and Environmental Earth Science, Miami University, Oxford, OH 45056, USA

\section{Juan Luis Alonso}

Departamento de Geología, Universidad de Oviedo,33005 Oviedo, Spain

\section{Submitted to:}

Gondwana Research

Invited Focus Review

Revised version: 16 July 2016 

34

\section{Abstract}

Olistostromes (sedimentary mélanges) represent the products of ancient submarine mass transport processes. We present a comparative analysis of the occurrences and internal structures of these sedimentary mélanges at a global scale with a focus on the Circum-Mediterranean, Appalachian and Circum-Pacific regions, and discuss their formation and time-progressive evolution in different tectonic settings. Lithological compositions, stratigraphy, and structural features of olistostromes reflect the operation of an entire spectrum of mass transport processes during their development through multi-stage deformation phases. The general physiography and tectonic setting of their depocenters, the nature, scale and rate of downslope transformation mechanisms, and global climatic events are the main factors controlling the internal structure and stratigraphy of olistostromes. Based on the tectonic settings of their formation olistostromes are classified as: (i) passive margin, (ii) convergent margin and subduction-accretion, and (iii) collisional and intra-collisional types. Systematic repetitions of these different olistostrome types in different orogenic belts provide excellent markers for the timing of various tectonic events during the Wilson cycle evolution of ocean basins. Olistostromes are best preserved in paleo active margins, covering vast areas of thousands of $\mathrm{km}^{2}$, where they underwent significant downslope translation, up to hundreds of kilometers. Incorporation of olistostromes into subduction-accretion complexes and orogenic belts takes place during discrete episodes of tectonic events, and their primary (sedimentary) fabric may be commonly reworked and overprinted by subsequent phases of tectonic and metamorphic events. We apply the basic nomenclature of structural geology, sedimentology and basin analysis in studying the internal structure, lithological makeup, and mechanisms of formation and extraordinary downslope mobility of olistostromes.

\section{Key Words}

Olistostrome, mass transport deposits, sedimentary mélange, subduction-accretion complex, orogenic belts 
1. Introduction

1.1. Objectives of this study

1.2. Definition of "olistostrome"

1.3. Olistostromes and Mass Transport Deposits

2. Olistostromes and tectonic settings of their formation

2.1. Passive margins tectonic settings and olistostromes

2.2. Convergent margin and subduction zone environments and olistostromes

2.3. Collisional and intra-collisional tectonic settings and olistostromes

\section{Preservation of olistostromes in the geological record}

3.1. Transformation during emplacement: olistostromes as ancient examples of mass transport complexes

3.2. The size paradox

3.3. Sheared olistostromes or tectonic mélanges? A long-standing debate

4. Mechanisms of olistostrome emplacement: interplay between structural geology and sedimentology

4.1. Large-scale olistostromes: a paradox in transition, internal fabric and emplacement?

4.2. Mesoscale kinematics indicators for mechanisms of olistostrome emplacement and translation

\section{Discussion: olistostromes as markers of tectonic events}

6. Concluding Remarks

\section{Acknowledgments}

References

Figure captions 


\section{Introduction}

106

\subsection{Objectives of this study}

In this paper, we present an overview of the occurrences of olistostromal deposits in the Circum-Mediterranean, Appalachian and Circum-Pacific orogenic belts, and discuss their internal structures and origins through a comparative global synthesis. We define the significance of olistostromes in the tectonic evolution of orogenic belts and exhumed subduction-accretion complexes, and examine the mode, nature and interplay of different geological processes that commonly operate during development of these "sedimentary mélanges". In the first part of the paper, we re-evaluate the spatial and temporal relationships between different types of olistostromes and the tectonic settings of their formation. Then, we show and discuss how the physical conditions of preservation may explain the apparent contrasts in the size and distribution of olistostromes in modern and ancient depositional settings. In the third part of the paper (Section 4), we examine and discuss the causes of observed variations in the size, internal fabric and run-out emplacement distance of olistostromes, while addressing their emplacement mechanisms. Following the work of Ogata et al. (2016), we also demonstrate that a proper application of the terminology of standard structural geology, in addition to using the sedimentological nomenclature, is highly useful in describing the internal fabric of olistostromes. The results of this global synthesis (Section 5) indicate that detailed, multidisciplinary studies of olistostromes are insightful for better understanding and constraining the temporal evolution of different stages of orogenic buildup and crustal exhumation in the Precambrian and Phanerozoic rock records, also pointing out their close correlation with global climatic events.

\subsection{Definition of "olistostrome"}

The term "olistostrome" (from the Greek "olistomai" - to slide - and "stroma" - accumulation -) was first introduced by Flores (1955) to define "sedimentary deposits occurring within normal geological sequences that are sufficiently continuous to be mappable, and that are characterized by 
lithologically and (or) petrographically heterogeneous materials, more or less intimately admixed, that were accumulated as a semi-fluid body". Flores $(1955,1956)$ further specified that olistostromes do not show true internal bedding, and that they can be differentiated in a matrix ("binder"), which consists of "prevalent pelitic, heterogeneous material", and dispersed "bodies of harder rocks" ("from pebbles to boulders up to several cubic $\left.\mathrm{km}^{\prime}\right)$. The introduction of the concept of "precursory olistostrome" by Elter and Trevisan (1973) played a fundamental role in better understanding the formation and evolution of collisional orogenic belts. This concept followed the wildflysch notion in the Alps presented earlier by Kaufmann (Kaufmann in Studer, 1872; Kaufmann, 1886; see Mutti et al., 2009 for a complete review), and defined the origin of gravitational chaotic deposits emplaced in front of advancing nappes. This conceptual development significantly increased our understanding of the relationships between tectonic and depositional processes in accretionary complexes and in fold-andthrust belts. Subsequently, the term olistostrome has been used extensively by the international geological community in reference to stratally disrupted, "chaotic" complexes and "exotic" sedimentary packages, resulted from various mass transport events.

In this extended definition, the "olistostrome concept" played a major role in long-lived debates, representing the counterpart of tectonic mélanges (i.e., olistostromal mélange or sedimentary mélange; see, e.g., Hsü, 1974; Raymond, 1984; Bettelli and Panini, 1985; Cowan, 1985; Camerlenghi and Pini, 2009; Festa et al., 2010a, 2012b, 2014b). Specifically, the term "allolistostome" (Elter and Raggi, 1965), which was proposed to describe olistostromes containing both native (i.e., intraformational) and exotic (i.e., extraformational) blocks (Table 1), focuses on the significance of sedimentary processes for the genesis of mélanges (i.e. sedimentary mélanges). The term "endolistostrome" (Elter and Raggi, 1965), which describes olistostromes containing only native blocks (Table 1), represents the equivalent sedimentary product of a "broken formation" (e.g., Raymond, 1984).

In most orogenic belts and exhumed subduction-accretion complexes, a strong morphological similitude of meso- to map-scale fabric elements exists between a block-in-matrix fabric of basin-wide 
olistostromes and a tectonic mélange. This resemblance remains at the base of a long-lasting debate on the nature and mode of geological processes that lead to the formation of chaotic rock

assemblages (i.e. gravitational vs. tectonics), particularly in those areas of well-preserved, exhumed subduction-accretion complexes, such as in the Western U.S. Cordillera and in the Circum-Pacific Region (see, e.g., Berkland et al., 1972; Aalto, 1981, 2014; Cloos, 1982, 1984; Raymond, 1984, Cowan, 1985; Brandon, 1989; Ukar, 2012; Wakabayashi, 2012, 2015; Platt, 2015, Raymond and Bero, 2015; Ukar and Cloos, 2015, 2016). The main aspect of the debate (see Alonso et al., 2006, 2015) is whether the "chaotic disruption" of rock assemblages beneath long-travelled nappe systems is a result of thrust related shearing ("tectonic brecciation", see, e.g., Bailey and McCallien, 1950; Vollmer and Bosworth, 1984; Burkhard, 1988; Jeanbourquin, 1994), or a product of mass wasting, which causes denudation of a nappe toe (e.g., Page, 1962; Boccaletti et al., 1966; Debelmas and Kerchkove, 1973; Elter and Trevisan, 1973; Aalto, 1981; Behr et al., 1982; Yilmaz and Maxwell, 1984; Alonso et al., 2006, 2015; Codegone et al., 2012a).

\subsection{Olistostromes and Mass Transport Deposits}

A vast amount of geophysical data acquired from modern continental margins show that mass transport deposits (MTDs) and complexes (MTCs) exist at various scales, and with varying abundance and characteristics, as controlled by the mode, nature and interplay of different geological processes in their tectonic setting of formation (e.g. Mosher et al., 2010; Yamada et al., 2012; Krastel et al., 2014; Lamarche et al., 2016, Moscardelli and Woods, 2016 and reference therein). These mass transport deposits represent either the products of a single depositional event or composite bodies originated by superposed, multiple events (e.g., Weimer, 1989; Weimer and Shipp, 2004; Della Valle et al., 2015), which may involve sediments with different degree of consolidation/lithification and grainsize (from clay to silt, to sand, to gravel size; Elverhøi et al., 2010; Strasser et al., 2011, 2012). MTDs and MTCs are commonly characterized by great internal heterogeneity and deformation, resulting in acoustic artifacts and transparent zones in 2D and 3D seismic imagery (Strasser et al., 2011, 2012; 
Gamboa et al., 2013; Ogata et al 2014a; Alves, 2015). However, an increasing amount of studies

based on marine geophysical data and core analysis show a partition of internal structural arrangement into discrete deformation domains, suggesting: (i) differential movement of discrete bodies of mass during translation and emplacement, (ii) episodic pulses during the same depositional event(s) and, (iii) interplay of different, synchronous mass transport processes (Vanneste et al., 2011; King et al., 2011; Ogata et al., 2012a; Joanne et al 2013; Omosanya and Alves, 2015).

Sedimentary rock bodies that formed as a result of mass transport processes widely occur in orogenic belts and in exhumed subduction-accretion complexes (Fig. 1), representing the ancient, "fossil" counterparts of modern MTDs and MTCs (Lucente and Pini, 2008; Ogata et al., 2012a). The term olistostrome that was first introduced by Flores (1955) to describe "chaotic" mass transport deposits with a shaly to pelitic, brecciated matrix in the Apennines (see Ogniben, 1952; Rigo de Righi, 1956) has been used extensively in the literature. Its application has been also widened beyond the original definition to encompass chaotic rock bodies with various matrix types, including sandy/silty (e.g., Abbate et al., 1970; Hsü, 1974; Erickson, 2011; Okay et al., 2012), volcanic (e.g., Kovacs, 1989), ophiolitic (e.g., Abbate et al., 1970; Gansser, 1974; Tekeli and Erendil, 1986; Lagabrielle, 1994), clast-sustained debrites (De Libero 1998), single blocks (olistoliths) or aggregates of slide blocks (Type C olistostromes of Lucente and Pini, 2003).

Olistostromes are in general composite deposits displaying superposed structures and complex stratigraphic relationships that developed during multiple events and mass transport processes (sliding, slumping, debris flow, blocky flow, turbidity currents; see, e.g., Lucente and Pini, 2003, 2008; Pini et al 2004; Festa et al., 2013, 2015c). Downslope motion of olistostromal deposits is enabled by the relative movement of discrete bodies of masses, causing progressive strata disruption and slideflow transformation (see, e.g., Lucente and Pini, 2003).

The extended use of the term olistostrome, which we follow in this study, can be applied to different types of fossil MTDs and MTCs, characterized by disrupted to "chaotic" internal fabrics, regardless of its original definition, which simply implies a genetic significance. Even with this broader 
definition, this term should not be used to indicate the parent sedimentological process, since it refers to the depositional product (i.e. deposit, accumulation). The existing inherent literature already points

\section{Olistostromes and tectonic settings of their formation}

The Circum-Mediterranean, Appalachian, and Circum-Pacific regions include some of the most extensively studied orogenic belts and exhumed subduction-accretion complexes, which display wellpreserved olistostromes of different ages (Fig. 2; Dilek, 2006). On the basis of a comparative analysis of exhumed, fossil olistostromes, and following the earlier work of Festa et al. (2010a, 2010b; see also Camerlenghi and Pini, 2009 and Festa et al., 2012b), we show that close relationships exist between the types of olistostromes and the tectonic settings of their formation (Table 2). Each type of olistostrome is also distinguished in terms of its composition and internal fabric, according to the source area and mechanism of emplacement.

\subsection{Passive margin tectonic settings and olistostromes}

Extensional tectonics and rifting-related geological processes commonly lead to the formation of various types of olistostromes during the course of passive margin evolution. Such olistostromes develop at the edges of thinned continental margins and carbonate platforms, at ocean - continent transition zones (OCT), and along oceanic core complexes (Table 2 and Fig. 3).

Along platform margins (Fig. 3C), olistostromes are generally the product of en-masse gravitational movements (e.g. debris flow, debris avalanches, and block sliding), and comprise megabreccias, olistoliths and olistolith fields (Table 2). They are commonly characterized by angular 
clasts and blocks (decimeters to several tens of meters in size; Figs. $3 \mathrm{I}, \mathrm{L}$ ) and subordinate and smaller, rounded clasts, which are older than the surrounding, fine-grained matrix. Such olistostromal

material is mainly sourced from intrabasinal topographic highs (e.g. horsts) and basin margin shoulders, all bounded by master normal faults. It can also be derived from tectonically uplifted, extended carbonate platforms along rifted continental edges (Figs. 3C, 3I, 3L). The matrix is predominantly made of pelagic limestone. Some of the best examples of this type of olistostromes exist in the Southern Alps and in the Northern Calcareous Alps (e.g., Castellarin, 1972; Channel et al., 1992; Böhm et al., 1995; Orner, 2001; Amerman et al., 2009), Apennines (e.g., Bernoulli, 2001; Graziano, 2001), Western Hellenides (Naylor and Hale, 1976; Ghikas et al., 2010), and Appalachians (e.g., Rast and Kohles, 1986; Bailey et al., 1989).

The most representative olistostrome types at OCTs (Fig. 3B) are poorly sorted ones with blocks commonly consisting of fine-grained carbonate, siliciclastic turbidites, and/or chaotic brecciated (i.e., matrix-supported) masses (Figs. 3G, H). Such lithological units are monomictic (i.e., dominated by native/intrabasinal clasts) when formed adjacent to rifted passive margins, and polymictic (i.e., mixing of native and exotic clasts) when developed proximal to an oceanic realm (Table 2), where the matrix material consists of deep-sea sediments. Polygenetic blocks and olistoliths may range from tens of meters to several kilometers in size. Hydroplastic deformation of blocks and clasts, liquefaction/fluidization, and soft-sediment deformation of the matrix (e.g., fluidal features, in-situ folding, boudinage, etc.) indicate that sediments were non- to poorly-consolidated at the time of olistostrome formation.

Reactivation of pre-existing extensional faults, fluctuations in sea-level and dissociation of gashydrates are the most common triggering mechanisms influencing slope instability, which is closely related to the shear strength of sediments. Olistostromes that formed in paleo OCTs are widely documented (Fig. 2) from the Circum-Mediterranean Region (e.g., Apennines, see De Libero, 1998; Pini et al., 2004; Hellenides-Albanides, see Smith et al., 1979; Shallo, 1990; Shallo and Dilek, 2003; Taurides, see Dilek and Rowland, 1993), the Central Appalachians (e.g., Jacobi and Mitchell, 2002; 
Wise and Ganis, 2009; Codegone et al., 2012a), and the Argentine Precordillera (Banchig, 1995, Keller, 1999; Alonso et al., 2008). The best examples of analogue MTDs occur in modern settings worldwide (e.g. Storegga, Saharan; Bugge et al., 1988; McAdoo et al., 2000; Mienert et al., 2003, and 10 12164 references therein).

In an oceanic realm (Fig. 3A), collapse of topographic highs of upper mantle abyssal peridotites, associated with mid-oceanic ridge settings and seamounts mainly form debris flows (e.g., Dilek and Rowland, 1993; Sarifakioglu et al., 2014; Liu et al., 2015) commonly consisting of clast- to matrixsupported angular clasts of mafic- to ultramafic rocks, embedded in a matrix composed mainly of pelagic limestone and/or medium -to coarse-grained sandstone with ophiolite-derived detrital material (Fig. 3E-F). Ophiolitic olistoliths and olistolith fields, related to block sliding and debris avalanche also occur close to mantle topographic highs and seamounts. Well-documented examples of olistostromes that developed at ancient mid-ocean ridge settings occur in the Western Alps and Pyrenees (e.g., Lagabrielle et al., 1984; Lagabrielle, 1994; Lagabrielle and Lemoine, 1997; Clerc et al., 2012; Balestro et al., 2014, 2015a, 2015b; Festa et al., 2015a; Tartarotti et al., 2015), in the Apennines (e.g., Abbate et al., 1970; Decandia and Elter, 1972; Bortolotti et al., 2001), and in the Western US- Cordillera (e.g., Saleeby, 1979).

\subsection{Convergent margin and subduction zone environments and olistostromes}

Olistostromes forming in these settings (Table 2 and Fig. 4), including fore-arc basins, are generally characterized by different degrees of stratal disruption, related to the consolidation state at the time of the slope failure and the final run-out distance of slide masses. Olistostromal material includes deformed sediments and native, extrabasinal or exotic rocks of different ages, generally older and more consolidated than intrabasinal components (Figs. 4E, F, G, I), which are sourced from the accretionary wedge front and/or wedge-top basins. Extrabasinal clasts and blocks comprise chunks or entire packages of sedimentary beds, which locally display their subduction-related tectonic fabric elements. The matrix varies from shale and generally fine-grained sediments (Figs. 4E, I) to medium- 
to coarse-grained sandstones (Figs. 4F, G). Pinch-and-swell structures due to boudinage

development, slump folds and "slump balls" are the most common features in the matrix, together with

meso-scale contractional and extensional duplexes, imbricated bedding, isoclinal folds, and shear zones (e.g., Taira et al., 1992; Yamamoto et al., 2009; Ogata et al., 2016). Debris flow, debris avalanches, sliding and slumping are the main modes of mass-transport processes that interact and overlap with each other during the formation of this type of olistostrome.

Tectonic over-steepening is the most important process, among several other factors, controlling slope instability at accretionary wedge fronts and retro-wedge fronts of doubly-verging accretionary wedges (e.g., Malavieille et al., 2016). This process is generally associated with "basal" and "frontal tectonic erosion" (sensu Von Huene and Lallemand, 1990), subduction erosion, seamount and ridge subduction (Anma et al., 2011; Kawamura et al., 2011), and thrust faulting and folding (see Martinez-Catalan et al., 1997; Marroni and Pandolfi, 2001; Von Huene et al., 2004; Ruh, 2016).

Upward rise of overpressurized fluids and fluidized/liquefied unconsolidated sediments sourced from out-of-sequence thrust faults and/or basal detachments of the frontal- and/or retro-wedges or subduction interface represents another possible triggering mechanism for slope failure (e.g., Barber et al., 1986; Lash, 1987; Conti and Fontana, 2011; Codegone et al., 2012b; Barber, 2013; Festa et al., $2013,2015)$. Some of the most important examples of subduction-related olistostromes occur in the Circum-Mediterranean orogenic belts, such as the Apennines (see Abbate et al., 1970; Elter and Trevisan, 1973; Bertotti et al., 1986; Pini, 1999; Marroni and Pandolfi, 2001; Malavieille et al., 2016), the Corsican and Western Alps (see Polino, 1984; Duran Delga, 1986; Deville et al., 1992), the Central Anatolian range (see Dangerfield et al., 2011; Sarifakioglu et al., 2014), the Mamonia Complex in SW Cyprus (see Swarbik and Naylor, 1980;), in the Appalachians (see, e.g., Lash, 1987; Wise and Ganis, 2009; Codegone et al., 2012a), and in the Circum-Pacific orogenic belts (e.g., Western US Cordillera, see Aalto, 1981, 2014; Raymond and Bero, 2015; Wakabayashi, 2015; Dominican Republic, see Hernaiz Huerta et al., 2012; New Zealand, see Chanier and Ferrière, 1991; Delteil et al. 2006; Japan, see Aoya et al., 2006; Yamamoto et al., 2009; Osozawa et al., 2009). This type of 
olistostrome has been also reported from fore-arc basins (Fig. 4D) at the rear of accretionary wedges (see Hitz and Wakabayashi, 2012 for a US-Western Cordillera example; Escuder-Viruete et al., 2015 for Hispaniola in the Carribean Plate; Lamarche et al., 2008 for the modern Kermadec fore-arc basin in NE New Zealand). In the Circum Mediterranean Region, Late Cretaceous fore-arc related olistostromes were derived from the internal side of the Alpine accretionary wedge (i.e., present-day 13317 14 16

Northern Apennines) and were then emplaced in a supra-subduction basin (Bertotti et al., 1986; Elter et al., 1991).

Emplacement of sections of lithospheric mantle onto continental margins represents another process, by which convergent margin - related olistostromes develop. Some of the best examples include the Al Hajar Mountains-Oman (e.g., Michard et al., 1991), Albanides (e.g., Bortolotti et al., 1996; Dilek et al., 2005), Hellenides (e.g., Jones and Robertson, 1991; Bortolotti et al., 2003; Ghikas et al., 2010), Western Anatolides (e.g., Okay et al., 2012), and the Coastal New Zealand (Delteil et al., 2006). Emplacement - related olistostromes become accreted (Fig. 4D) as a section of subducting oceanic lithosphere is thrust into the accretionary wedge as accretionary type ophiolites (Dilek and Furnes, 2011, 2014). Blocks derived from both oceanic and continental crustal assemblages characterize this type of olistostrome. Oceanic material is sourced from the front of an obducting ophiolite sheet (i.e., obduction-related olistostromes), and continental material from the continental margin succession beneath the advancing ophiolite nappe (Bortolotti et al., 2013). Debris flows consisting only of ophiolitic blocks and associated sedimentary rocks may also be emplaced during an intra-oceanic obduction stage (Lagabrielle et al., 1986) when a fragment of oceanic lithosphere tectonically overrides another oceanic plate.

\subsection{Collisional and intra-collisional tectonic settings and olistostromes}

These types of olistostromes (Table 2; Figs. 4B, C), particularly the intra-collisional ones, represent the majority of examples documented from ancient orogenic belts in the CircumMediterranean Region and from the Appalachians, and are directly related to the early phases of 
mountain-building processes. Festa et al. (2010a, 2012; see also Camerlenghi and Pini, 2009) subdivided these types of olistostromes into three main sub-types (i.e., sub-nappe, intra-nappe and epi-nappe) on the basis of their relative position with respect to the allochthonous nappe structures. Sub-nappe olistostromes are, in turn, subdivided into: (i) precursory olistostromes, and (ii) 13142

olistostromal carpet (Table 2 and Fig. 4C). The precursory olistostromes (sensu Elter and Trevisan, 1973) consist of classic olistostromes (and/or wildflysch; e.g. Mutti et al., 2009) with a block-in-matrix fabric, emplaced by cohesive debris flows (Fig. 4L) and/or block avalanches in migrating foredeep basins (e.g., Bird, 1969; Root and MacLachlan, 1973, Behr et al., 1982; Frisch, 1984; Pini, 1999; Lucente and Pini, 2003, 2008; Masson et al., 2008; Festa et al., 2010b, 2012b; Vezzani et al., 2010; González Clavijo et al., 2016). This type of olistostrome is an end product of a "closure event", recording the depositional deactivation on top of the foredeep turbidite successions. It forms before the advancement of thrust-related deformation and subsequent incorporation into a collisional belt. Some of the excellent examples include the Aveto and Macigno Formations in the Northern Apennines (e.g. Lucente and Pini, 2003, 2008), and the Tarakli Flysch in Turkey (e.g., Catanzariti et al., 2013). Olistostromal carpets (Pini et al., 2004) comprise laterally and vertically coalescing and overlapping aprons of failed sediments, and develop as a result of protracted debris flow activities (Fig. 4C) and avalanches in front of advancing nappe sheets. Such avalanche deposits are then structurally overridden by allochthonous nappes during their tectonic migration. Blocks and discrete slides are sourced from nappe fronts (Fig. 4M), whereas loose to poorly-consolidated sediments originate from thrust-top and intra-slope basins and slope deposits emplaced atop the nappe front (Alonso et al., 2006).

In this framework superposition of tectonic shearing (Fig. 4N) exerted by nappe emplacement on primary gravitational fabric elements of olistostromes typically complicates the final products. Some of the salient examples have been documented, for example, from the base of the Taconic thrust front in the Appalachians (see, e.g., the Huston River mélange of Vollmer and Bosworth, 1984; Bosworth, 1989; the Poetstenkill Gorge mélange of Festa et al., 2012a; some mélanges in the Hamburg Klippe 
of Lash, 1987; Codegone et al., 2012a), in the Central Alps (Habkern mélange of Kempf and Pfiffner,

2004), some mélanges at the base of the Ligurian Units in the Northern Apennines (e.g., Lucente and Pini, 2008; Ogata et al., 2012a; Festa et al., 2013) and in the Southern Apennines (e.g., Mattioni et al., 2006; Festa et al., 2010b, Vezzani et al., 2010), in the Anatolide-Tauride orogenic belts (e.g., Bailey and McCallian, 1950, 1953; Dilek and Delaloye, 1992; Dilek et al., 1999; Sarifakioglu et al., 2012), Othris Mountain in Greece (Smith et al., 1975), and in Taiwan (Page and Suppe, 1981).

Intra-nappe olistostromes (Table 2), which develop as a result of tectonic deformation during nappe translation, mainly consist of blocks of intrabasinal origin and/or portions of older sedimentary successions embedded within a matrix made of the same lithologies. Conglomerates, breccias megabreccias, and large isolated olistoliths can be the products of both rock-fall and gravity flow processes. Large, intra-nappe shear zones, associated with out-of-sequence thrusting, may form olistostromal carpet-like intervals, only differing from the typical ones in their position within the nappe (Festa et al., 2010a and reference therein).

Epi-nappe olistostromes (Table 2 and Fig. 4C), which form by gravitational instability along the margins of piggyback, thrust-top, wedge-top, episutural and satellite basins (Fig. 4O), represent the most common types in the Circum-Mediterranean Region. Both blocks and the matrix in these olistostromes are sourced from the stratigraphic successions that are tectonically dismembered and imbricated in thrust sheet stacks (e.g., Papani, 1963; Bettelli and Panini, 1989; Bettelli et al., 1989, 1994; Pini, 1999; Panini et al., 2002; Ferrière et al., 2004; Remitti et al., 2011, Ogata et al., 2012b, 2014a; Festa and Codegone, 2013; Festa et al., 2005, 2015b, 2015c).

Triggering mechanisms for gravitational instability in collisional and intra-collisional settings are mainly seismic shocks emanating from thrust faulting. However, in epi-nappe settings climatic forcing may also play a significant role, primarily by enhancing the sediment supply and by causing important variations in sea-level and subsidence rates. 


\section{Preservation of olistostromes in the geological record}

392 34

Relationships between different types of olistostromes and their tectonic settings of formation, as described above, are directly influenced by their preservation potential in the geological record. In contrast to modern tectonic settings, in which the majority of such deposits occur in association with gravitational instability along passive margins (e.g., Macdonald et al., 1993; Mienert et al., 2003; Camerlenghi and Pini, 2009), olistostromes originated from active margins are more widespread in ancient orogenic belts and exhumed subduction-accretion complexes (Fig. 5). Moreover, submarine landslides, described on modern continental margins, are documented to be several orders of magnitude larger in cross-sectional area then their equivalent olistostromes (e.g., Woodcock, 1979).

In the following, we provide independent lines of evidence to discuss and reevaluate these existing apparent dichotomies, taking into consideration that olistostromes may represent either the product of a single depositional event (i.e., MTD) or composite bodies (i.e., MTC), the origin of which is due to superposed events (Heck and Speed, 1987; Macdonald et al., 1993; Lucente and Pini, 2003; Ogata et al., 2012a, 2012b, 2014a; Pini et al., 2012).

Three main factors effectively influence the preservation of olistostromes: (i) their transformation during transfer and emplacement, (ii) their size, and (iii) the role played by the overprinting of tectonic deformation during subsequent orogenic stages.

\subsection{Transformation during emplacement: olistostromes as ancient examples of mass- transport complexes}

Olistostromes, particularly large ones, are complex rock assemblages, whose formation may involve the entire spectrum of mass transport processes (Lucente and Pini, 2003), and they comprise discrete sub-units, subdivided on the basis of composition, provenance, structures, and sense of movement (Figs. 6 and 7). These sub-units are interpreted as products of discrete slide masses moving differentially, and of multiple, overlapping submarine en-masse flow processes (Ogata et al., 
2014b; see also Strachan, 2002; Lucente and Pini, 2003; Ogata et al., 2012b). The final anatomy of

the olistostrome, as a slide body, depends on the extent of segregation/separation among the different

internal structural facies associations (Fig. 7). Analogous to the concept of "flow efficiency" for turbidites as introduced by Mutti et al. (1999), olistostromes characterized by high efficiency may, for example, separate different facies populations horizontally during their downslope transport, hence forming deposits with laterally varying facies associations and marked boundaries (Fig. 7). Such deposits are expected in passive margins, where continental slopes are characterized by relatively smooth morphologies and constant gradients. On the other hand, low efficiency slides appear as composite bodies characterized by strong lateral-vertical variations, horizontal heteropy, and interfingering of different facies associations as a result of their incomplete/partial segregation. These types of deposits likely develop in depositional settings having a complex physiography with structurally confined depocenters separated by intrabasinal highs. Such features constitute local morphological barriers and hence favor flow transformations on short distances.

Recent studies (Pini et al., 2012; Lucente and Pini, 2003, 2008; Ogata et al., 2012b) have shown that basin-wide olistostromes or mass-transport complexes (MTC) in the Northern Apennines consist of different structural associations: (i) mud-rich chaotic deposits characterized by the cohesiveviscous behavior of a viscous matrix (Type $1 \mathrm{MTC}$; see Fig. 7(3)), including $\mathrm{cm}$ - to m-sized lithic blocks randomly distributed in a brecciated or clastic matrix. The matrix may sustain bedding packages that are tens of meters and up to kilometers in size (floaters); (ii) clastic matrix represented by an unsorted, liquefied/fluidized mixture of different grain-size populations, dispersed within a finegrained lithology (Type 2 MTC). Such matrix material may show the characteristic features of a hyperconcentrated suspension (sensu Mutti, 1992; see also Callot et al., 2008; Ogata et al., 2012b, 2014a), commonly arranged as bipartite bodies with a block-dominated portion overlying a matrix-dominated one. This kind of matrix may originate from a complex debris flow carrying coherent blocks (meters- to hundreds of meters wide), which are commonly arranged in isolated slump-like folds (blocky-flow deposits sensu Mutti et al., 2006; see Fig. 7(2)); (iii) slump-slide-like MTC (Type 3 MTC; see Fig. 7(1)) 
developed in sandy sediments (e.g. foredeep turbidites), in which transport and emplacement are 34

allowed by differential movement of individual bed-packages of different dimensions. The relative movement is accommodated along ductile shear zones, which are marked by mm-thick "films" of unsorted silty material and $\mathrm{cm}$ - to tens of $\mathrm{cm}$-thick deformation/disaggregation bands in sandstones. These shear zones develop along with transportation / rotation of clasts and elutriation of finer-grained clastic material populations (see also Dykstra, 2005).

The Miocene Cascaglia - Monte della Colonna body $\left(>350 \mathrm{~km}^{2}\right.$ and up to $300 \mathrm{~m}$ thick; see Lucente and Pini, 2003, 2008), the Oligocene Specchio Unit (about $1500 \mathrm{~km}^{2}$ and average thickness of $100 \mathrm{~m}$; see Ogata et al., 2012, 2014), the Late Oligocene - early Miocene Val Tiepido-Canossa argillaceous breccias (over an area of about $300 \mathrm{~km}$ long and tens of kilometers wide, and up to $300 \mathrm{~m}$ thick; see Bettelli and Panini, 1985; Panini et al., 2002; Remitti et al., 2011; Festa et al., 2015c and reference therein) in the Northern Apennines, the Paleogene carbonate "megabreccia" (23 megabeds uo to $1500 \mathrm{~km}^{2}$ and up to $260 \mathrm{~m}$ thick each) of the Friuli Basin in the Southern Alps (Ogata et al., 2014b), and the Eocene foredeep carbonate megabreccias in the south-central Pyrenees (Payros et al., 1999; Ogata et al. 2012b), represent some of the best examples of basin-wide olistostromes. These types of olistostromes display more than one type or all the structural associations described above.

\subsection{The size paradox}

Woodcock (1979) has pointed out earlier a size dichotomy between ancient submarine slide deposits and olistostromes observed in outcrops and those identified in modern continental margins (Fig. 8; see also Macdonald et al., 1993; Lucente and Pini, 2003; Camerlenghi and Pini, 2009; Pini et al., 2012; Ogata et al., 2014b). Modern submarine slides appear to be, on average, several orders of magnitude larger in cross-sectional area than their inferred ancient counterparts (Fig. 8). Thus, the questions remain as to whether the upper limit of the size of ancient on-land olistostromes is a 
function of exposure and/or whether it reflects a real change in the magnitude of processes responsible for their formation (see Woodcock, 1979; Macdonald et al., 2003; Pini et al., 2012).

We can approach this size paradox to the first order by recognizing that olistostromes largely 10 1471 12 represent mass-transport complexes (Pini et al., 2012), showing substantial similarities in size (Fig. 8), distribution, recurrence interval (see below), and run-out distance (Fig. 9) with modern submarine slide deposits in different tectonic environments (e.g., Camerlenghi and Pini, 2009; Festa et al., 2010a; Pini et al., 2012; Ogata et al., 2014a). For example, the Makran olistostrome, which is associated with an accretionary complex, represents one of the largest and best-preserved examples of an ancient sedimentary chaotic rock unit yet observed (about $42.000 \mathrm{~km}^{3}$ and $10.000 \mathrm{Km}^{2}$ distributed over an area of $72.000 \mathrm{~km}^{2}$, Burg et al., 2008). Direct comparisons are possible in similar tectonic and depositional settings, and the best examples include the Oligocene wedge-top basins of the Northern Apennines (e.g., Bettelli et al., 1989; Pini, 1999; Remitti et al., 2011; Ogata et al., 2012c, 2014a; Pini et al., 2012; Festa et al., 2015c) and the modern Kumano Basin in the Nankai forearc setting (e.g., Strasser et al., 2011), the Poverty Unit in the Hikurangi margin of New Zealand (e.g., Mountjoy and Micallef, 2012; Ogata et al., 2014a), and the MTCs from the Southern Magdalena Fan, offshore Colombia (Ortiz-Karpf et al., 2016), the Late Cretaceous Casanova Complex of the Northern Apennines (e.g., Bertotti et al., 1986; Elter et al., 1991) and the Matakaoa submarine instability complex in the Kermadec fore-arc basin in New Zealand (Lamarche et al., 2008). Some other examples also include the Miocene Makran olistostrome (Burg et al., 2008), the modern accretionary wedge of the Sunda Arc (Moore et al., 1976) and the Gibraltar Arc - Gulf of Cadiz (Medialtea et al., 2004), the Late Carboniferous Porma mélange and other mélanges of the Cantabrian Zone (Alonso et al., 2006, 2015; Martin-Merino et al., 2014), the Ordovician mélanges of the Argentine Precordillera (Banchig, 1995; Von Gosen et al., 1995; Alonso et al., 2008; Sobiesiak et al., 2016), the Paleogene carbonate megabreccia units in NW Italy and Slovenia (Ogata et al., 2014b), the Early Miocene Nataraja submarine slide (Calvès et al., 2015) and the modern Giant Chaotic body offshore of Gibraltar (Torelli et al., 1997). 


\subsection{Sheared olistostromes or tectonic mélanges? A long-standing debate}

In ancient orogenic belts and exhumed subduction-accretion complexes with a record of multiple deformational events, olistostrome fabrics are commonly overprinted and significantly reworked by tectonics (Figs. 10D-E, and 11), extremely complicating their distinction from tectonic mélanges (e.g., Raymond, 1984; Cowan, 1985; Pini, 1999; Festa et al., 2013 and reference therein). This is the case, for example, for olistostromal carpets formed at the base of intra-collisional nappes, and for olistostromes overprinted by thrust faulting and tectonic shearing in subduction zones and accretionary complexes. This problem, which remains at the core of a long-standing debate, especially in the Western US Cordillera (e.g., Berckland et al., 1972; Silver and Beutner, 1980; Cloos, 1982; Raymond, 1984; Cowan, 1985; Brandon, 1989; Platt, 2015; Raymond and Bero, 2015; Ukar and Cloos, 2015; Wakabayashi, 2015 and reference therein) and in all exhumed subduction-accretion complexes throughout the world (e.g., Pini, 1999; Alonso et al., 2006, 2008 2015; Şengor, 2006; Festa et al., 2010a, 2012b; Balestro et al., 2015b; Wakita, 2015), revolves around the mechanisms of incorporation and mixing of exotic blocks within a matrix. Although the "flow mélange model" (Cloos, 1982, 1984) is the most important mixing process at deeper structural levels within subduction channels (Figs. 10B, C), gravitational processes represent the most effective ways in incorporating exotic blocks into a shale matrix at shallow structural levels (e.g., Cowan, 1985; Alonso et al, 2006; Festa et al., 2012, Platt, 2015). Exotic blocks, which are supplied by mass transport events, for example, at the front of a nappe (Figs. 10A-C), can be easily misinterpreted as blocks incorporated through tectonic slicing and shearing, and vice versa, because the two end products (i.e., olistostromes overprinted by tectonics and tectonic mélanges) show strong morphological similarities of rocks with similar block-in-matrix fabrics (Figs. 10D-E, 11). The composition of the matrix, however, may provide significant information on the tectonic setting of formation (see Section 2). For example, the occurrence of sandstone-matrix mélanges, rather than shale matrix ones, indicates that gravitational processes, which formed olistostromes, contributed to the formation of at least part of the 
well-known Franciscan Complex (e.g., Aalto, 1981, 2014; Raymond and Bero, 2015 and reference therein).

Olistostromes with bedded "floaters", such as slide blocks composed of specific turbidite facies and grain-flow deposits, embedded in a sandstone matrix, are stratigraphically and sedimentologically consistent with parts of lower slope-base of slope sedimentary successions, arguing against flow mélange origins in a subduction channel (Raymond and Bero, 2015). In this framework, the compositional attributes of matrix and blocks may provide significant clues to better understand the evolution of subduction complexes and the structural architecture of the frontal part of accretionary wedges. Accumulation of thick and sandy (and/or heterogeneous) sediments within an accretionary complex (Figs. 10B, C, 11) may result in frontal accumulation of thick wedges of sandstone-dominated mass transport complexes (e.g., Ernst, 1977; Seely et al., 1994; Clift and Vannucchi, 2004; Raymond and Bero, 2015), rather than thinner, shale-matrix fault zone mélanges, which may form and accrete incrementally (e.g., Cowan, 1985; Festa et al., 2010a; Rowe et al., 2013). This, in turn, may suggest that in some cases a significant reassessment of transfer mechanisms and amounts of material transferred from the overriding plate to the subducting plate is required (see Raymond and Bero, 2015 for a detailed discussion). Submarine mass transport complexes and olistostromes, occurring in frontal parts of accretionary wedges, may locally reach volumes up to thousands of $\mathrm{km}^{3}$ in size (e.g., Macdonald et al., 1993; Hampton et al., 1996; Collot et al., 2001; Lewis et al., 2004; Burg et al., 2008; Contreras-Reyes et al., 2016; Ruh, 2016; see Section 3.2 and Fig. 10A). Thus, they play a crucial role in controlling the thickness of accretionary wedges, their internal architecture and lateral morphological variations. Different trajectories may be followed (Figs. 10B, C) in accretionary versus erosional margins.

\section{Mechanisms of olistostrome emplacement: Interplay between structural geology and sedimentology}


A systematic examination of basin-wide olistostromes indicates unusually fast-rated processes and long-distance mobility (tens to hundreds of kilometers) of thick (200-300 m) cohesive olistostromes (Fig. 9). This observation contrasts with their internal fabric and composition and with the fact that they do not fully transform during emplacement. Cohesive olistostromes (e.g., Type 1 MTD of Pini et al., 2012) should be deposited by relatively slow-moving slide masses, in which the movement is achieved through laminar "viscous" shear zones in a clay-dominated matrix (Fig. 12). Thus, thick cohesive olistostromes are not expected to have high mobility and long run-out into a basin.

\subsection{Large-scale olistostromes: a paradox in transition, internal fabric and emplacement?}

Detailed field observations have shown that the emplacement of some cohesive olistostromes, such as clay-rich cohesive debris flows, may have been a fast-paced process capable of carrying material for long distances when sustained by a thin (up to a meter in thickness) and continuous, basal shear zone. Much of deformation takes place along this basal shear zone, which represents a hydroplaning "carpet" (Fig. 12B) consisting of a liquefied/fluidized mixture of water and loose sediments (e.g., Pini et al., 2012; Ogata et al., 2014b; Festa et al., 2015c). This inference is consistent with observations from both modern and submarine landslides, and laboratory experiments (e.g., De

Blasio et al., 2006 and reference therein). The process of "autoacephalation" proposed by Parker (2000; see also Harbitz et al., 2003) for slide masses undergoing hydroplaning can explain the occurrence of isolated olistoliths and detached parts of cohesive debris flow in the form of fore- and out-runner blocks.

In the Northern Apennines, for example, brecciated substratum intervals, decimeters to meters in thickness, with soft clasts in marl layers usually occur discontinuously at the base of cohesive olistostromes over an area of about $300 \mathrm{~km}$ long and tens of kilometers wide (Festa and Codegone, 2013; Festa et al., 2015b, 2015c). These relationships and structures suggest a non-indurated state of 
572 the underlying sediments (i.e. overridden substratum) during motion and immediately after the

emplacement of olistostromes. Formation of the breccia was spatially and temporally associated with

$\mathrm{mm}$ - to $\mathrm{cm}$-thick, sub-vertical flame-shaped sedimentary injections, representing the products of fluidoverpressure driven deformation of the substratum as a result of the dynamic loading of the moving slide mass. Centimeters- to decimeters-thick "mylonite-like" shear zones (Figs. 12C, D, E, F) occur at the base of and within the olistostrome and display strong deformation fabrics in both soft- and hardmicroclasts and clasts. These structures define a constriction plus flattening type (i.e., prolate plus oblate) strain ellipsoid, with a prevailing component of stretching along the direction of flow and a minor component of planar flattening due to compaction. The shear zones represent the loci of concentrated viscous deformation, which either acted in combination with basal "carpet" hydroplaning or in isolation, after dissipation of the basal fluid overpressure during the final stages of the emplacement of a slide mass (see also Ogata et al., 2014a).

Combination of hydroplaning and shearing during downslope translation of submarine landslides is an efficient mechanism for the emplacement of both basin-wide olistostromes and some "gravitational nappes" characterized by long to unusually long run-out distances achieved in relatively short time spans. This mechanism may also explain the great mobility of olistoliths up to $10^{5}-10^{6} \mathrm{~m}^{3}$ in volume, comparable in character and size to the modern out-runner blocks. Such olistoliths also occur as isolated elements in front of large olistostromes or nappe sheets (e.g., in the External Ligurian Units), or at their base because of subsequent downslope translation of the olistostromes or nappes (e.g., Central Appalachians, see Codegone et al., 2012a; Porma mélange, see Alonso et al., 2006, 2015). These kinds of olistoliths may also originate during rapid deceleration of a landslide front, whereby over-consolidated blocks with high momentum persist in their inherited motions (e.g., De Biasio et al., 2016). In modern examples, they may show tens of kilometers run-out distance, ahead of the front of submarine landslides along a less than one degree average slope (e.g., Prior et al., 1987; Nissen et al., 1999; Canals et al.,. 2004; Nielsen and Kujpers, 2004). 


\subsection{Mesoscale kinematic indicators for mechanisms of olistostrome emplacement and translation}

We describe here a wide range of mesoscale structures in discussing various deformation mechanisms of olistostromes that favor their downslope mobility. This topic is significant to better understand other factors controlling the preservation and significance of olistostromes in the evolution of orogenic belts.

Mechanisms supporting the extraordinary downslope mobility of olistostromes are explained with the application of structural geology tools in addition to classic sedimentological ones (Ogata et al., 2016; Fig. 13). Mixed pure- and simple-shear mechanisms due to the coupled, cyclic action of dynamic/static loading and the differential movements of a slide mass and its internal components, produce a variety of asymmetrical structures ranging from microscopic to outcrop-scale (Fig. 13). The shape, spatial arrangement, and geometric relationships of these structures can be used as standalone kinematic indicators to record local differential movements between the internal slide parts or in combination for a robust interpretation of the general paleo-transport directions. These structures, specifically distributed within a slide body, are interpreted as products of soft sediment deformation developed at low confining pressures (i.e. superficial conditions) involving undrained, water-saturated, poorly- to un-consolidated sediments, both failed and eroded from the overridden seafloor. This interpretation is further supported by microscopic analyses highlighting independent particulate flow with minor or no grain breakage (see, e.g., Ogata et al., 2014b).

Close morphological similarities with ductile (and brittle-ductile) structures documented in structurally deeper metamorphic rocks allow us to adopt some of the descriptive, non-genetic terminology classically used in structural geology (e.g., Passchier and Throw, 2005). The most common structures widely recognized in all the different examples of analyzed olistostromes include the following (Ogata et al., 2016): 
(1) Asymmetric boudinage structures (Fig. 13(1)) recording layer-parallel extension of poorlyconsolidated interbeds, having high rheological contrasts. They display characteristic pinch-andswell geometries and a preferred alignment of phacoidal and lozenge-shaped structures. The single asymmetrical elements define the associated stress direction;

(2) Pseudo-Sigma structures (Fig. 13(2)), reminiscent of typical Sigma structures of tectonically induced ductile deformation. These structures consist of $\mathrm{mm}$ - to $\mathrm{m}$-sized, asymmetric, sigmashaped objects deformed by simple shear-related viscous flow. They comprise cohesive lithologies, distinctly different from the surrounding matrix, which commonly originates from the disaggregation of the transported and eroded, layered sediments;

(3) Pseudo S-C structures (Fig. 13(3) and 12F), comprising discrete zones (millimeters to centimetersthick shear bands) of high shear strain (i.e. C-surfaces) that bound systematic, pervasive, sigmoidal foliation planes (i.e. S-surfaces). These planar discontinuities are commonly represented by disaggregation, deformation-and compaction-bands;

(4) Intrafolial folds (Fig. 13.4) with their main reference surfaces traceable laterally into unfolded layers. They can be $\mathrm{cm}$ - to $\mathrm{m}$-long and display marked thickening of their hinge zones. They show an overturned, isoclinal, sheath-type geometry in three-dimensions, similar to fault-propagation folds, and may evolve into detached folds;

(5) Low-angle shear zones (Fig. 13(5)), ranging in thickness from millimeters to meters and in length from centimeters to tens of meters. They can be subdivided in roughly symmetrical (with respect to the principal slip surface/interval) elements represented by damage- and core-zones, whereby transition from relatively undeformed to completely disrupted sediments (i.e. matrix) occurs in short distances. The rate and magnitude of accommodated deformation are proportional to the abundance of matrix material. Disaggregation-deformation-compaction bands are the most common features and locally occur in swarms;

(6) Cuspidate injectites (Fig. 13(6)), are represented by pipe-, sheet- (i.e. linear), and wedge-shaped (i.e. planar) matrix injections. They range in thickness from millimeters to meters and in length from 
centimeters to tens of meters. As over-pressurized, liquefied or fluidized sedimentary matrix material penetrates into slide blocks via hydrofracturing and/or by passively flowing into the lowpressure zone, these injectites form systematically along the bounding surfaces between the matrix-rich and coherent lithologies (e.g. blocks margins, basal contact). They hence provide directional information on the shear sense and relative movements of the overpressurized matrix flow;

(7) Duplex-type structures (Fig. 13(7)), are formed as a result of local imbrication of isolated blocks along flat-ramp to sigmoidal shear surfaces. They can be centimeter to tens of meters in size, and are vertically bounded above and below by major shear surfaces merging laterally into a single shear plane;

(8) Rootless folds (Fig. 13(8)), representing completely detached, isolated slump-type fold hinges, dispersed within a fine-grained matrix. In three dimensions they resemble asymmetric, isoclinal sheath folds with marked thickening of their hinge zones. They commonly include sedimentary matrix injections along their outer-arcs, limbs and cores. These structures, along with the intrafolial counterparts (see above), are the most effectively used kinematic indicators for interpreting paleotransport directions (e.g. Lucente and Pini, 2003; Strachan and Alsop, 2006; Ogata et al., 2014b). In summary, the identification of these structures in outcrops helps us correctly interpret the general and local slide kinematics of olistostromes, and hence complementing the small-scale datasets provided by drill cores, borehole logging, and geophysical imaging.

\section{Discussion: olistostromes as markers of tectonics events}

Olistostromes and mass-transport deposits are predominantly gravitational in origin and occur widely in ancient orogenic belts and exhumed subduction-accretion complexes. Close relationships between different types of olistostromes and tectonic settings of their formation (Camerlenghi and Pini, 
2009; Festa et al. 2010a, 2012b), the degree of their preservation in the geological record, and the analysis of their internal fabric revealing the potential mechanisms of their emplacement allow us to evaluate the significance of olistostromal occurrences in the evolution of ancient orogenic belts and exhumed subduction complexes. There remain two major questions: whether or not olistostromes represent the local markers of regional tectonic events, and whether their emplacement is a recurrent event in a particular tectonic setting.

The discontinuous distribution of olistostromes in space and time within ancient orogenic belts and subduction-accretion complexes may reflect significant physical and mechanical changes in their depositional settings of formation. Tectonic events commonly show a strong correspondence with transgressive-regressive sedimentation cycles, which are, in turn, in agreement with the local and eustatic sea level variations (Fig. 14; see e.g., Vail and Mitchum, 1980; Haq et al., 1987; Haq and Shutter, 2008; Snedden and Liu, 2010; see Fig. 14). Eustatic sea level fluctuations commonly result in the formation of global unconformities at sequence boundaries of sedimentary cycles. Thus, except for local cases, the length of each time interval of olistostrome emplacement corresponds to a single tectono-sedimentary cycle (Fig. 14). Such a cycle can be defined, for example in active margins, by a time window between the nappe emplacement and the related accumulation of regressive sedimentary sequences and the subsidence initiation that facilitates mass-transport processes and the formation of olistostromes in frontal parts of advancing nappe sheets (e.g., Scherba, 1989; Lucente and Pini, 2008; Festa et al., 2015c). The main stages of olistostrome emplacement in the CirumMediterranean Region (i.e., Apennines, Betic Cordillera, Rif, and Hellenides-Albanides) and the Alps (the Ligurian Alps, Carpathian, Pyrenees, and Caucasus) during the late Cenozoic may be attributed to the same or closely similar time intervals (Fig. 14), which correspond to main tectonic stages and regional-scale transgressive-regressive cycles (Scherba, 1989). Although olistostromes developed during each single tectonic stage do not occur everywhere in all these regions, the majority of them are confined to (Fig. 14) the middle Eocene, late Eocene-early Oligocene, late Oligocene-early Miocene, late-early Miocene (Burdigalian), late Miocene (late Messinian)-early Pliocene (see, e.g., 
Sherba, 1989; Pini, 1999; Lucente and Pini, 2003, 2008; Camerlenghi and Pini, 2009; Festa et al., 2010b, 2013, 2015b, 2015c; Ślączka et al., 2012; Festa and Codegone, 2013; Ogata et al., 2012b,

2014a). We thus posit that these specific time windows correspond to different stages of intracontinental tectonics, starting with the Eocene collision between Adria and Europe, after the closure of the Tethyan oceanic realm. Although, in general, some structural differences exist between the northern and southern branches of the Circum-Mediterranen region, each stage corresponds to a main phase of nappe transport toward the foreland until the final closure of Neotheys (e.g., Sherba, 1989; Lucente and Pini, 2008; Camerlenghi and Pini, 2009; Festa et al., 2010b and reference therein). Similar observations can be made in different orogenic belts, and within the remnants of exhumed ancient subduction-accretion complexes in the Circum-Mediterranean Region, Appalachians and Circum-Pacific Region, independently of the ages of different tectonic events and the characteristics of different orogenic stages (Fig. 14).

In all these orogenic belts, the temporal and spatial distribution of different types of olistostromes commonly represent different tectonic stages within the Wilson cycle evolution of ocean basins, from the early rift-drift to later subduction, collision, and orogenic exhumation (Fig. 14; Dilek and Whitney, 2000; Dilek, 2003; Dilek and Newcomb, 2003). One of the best examples of such time-progressive olistostrome development can be given from the Circum-Mediterranean region, where different types of olistostromes reflect different stages of the tectonic evolution of the Alpine Tethys. For example, different phases of olistostrome emplacement have been well documented to be associated with the Late Jurassic rifting stage during the opening of the Alpine Tethys (e.g., Elter and Trevisan, 1973; De Libero, 1998; Cieszkowski et al., 2012; Clerc et al., 2012; Balestro et al., 2015a; Festa et al., 2015a; Tartarotti et al., 2015), the Late Jurassic - Early Cretaceous collapse of passive margin carbonate platforms (e.g., Castellarin et al., 1972; Cecca et al., 1981, Fazzuoli et al., 1985; Bernoulli, 2001; Graziano, 2001; Ślączka et al., 2012), the Late Cretaceous - early Paleogene subduction stages (e.g., Elter and Trevisan, 1973; Marroni and Pandolfi, 2001), and the Eocene - Miocene collisional and intra-collisional stages (e.g., Abbate et al., 1970; Bettelli et al., 1989; Pini, 1999; Panini et al., 2002; 
Lucente and Pini, 2003, 2008; Camerleghi and Pini, 2009; Festa et al., 2010b, 2015c; Remitti et al., 73 2011; Ogata et al., 2012c, 2014a; Codegone et al., 2012b).

In the Central Appalachians, different types of olistostromes and olistoliths mark a continuum of tectonic events (Fig. 14) from the early stages of subduction of the Laurentian continental margin beneath an intraoceanic island arc system in the middle Ordovician (e.g., Epstain, 1972; Lash and Drake, 1984; Lash, 1987; Ganis et al., 2001; Ganis and Wise, 2008; Codegone et al., 2012a) to the early-late Ordovician and late Ordovician precursory olistostrome emplacement (Martinsburg Formation) in a foreland basin of the initial Appalachian orogenic belt during the collision stage (e.g., Root and MacLachland, 1978; Lash and Drake, 1984; Lash, 1987; Codegone et al., 2012a). A comparable olistostromal sequence characterizes the Taconic foreland basin extending from the New York State to Vermont and Southern Quebec (Berry, 1962; Bird, 1963; Stevens, 1968; St Julien and Hubert, 1975; Lash, 1985; Vollemer, 1980; Bosworth and Vollmer, 1981; Bosworth, 1989; Schroetter et al., 2006; Festa et al., 2012a), where they record different stages of the Taconic orogeny. On the East Coast of New Zealand in the SW Pacific, Delteil et al. (2006) have documented the occurrence of successive tectonic events marked by different types of olistostromes spanning a time interval from the Eocene to the early Miocene.

The recurrence time of olistostrome emplacement thus appears to be directly related to the frequency of tectonic stages, their magnitude, and their control on depositional cycles (Fig. 14). In the continuum of deformation characterizing different stages of the orogenic belt evolution, the seemingly discontinuous distribution of olistostromes with different ages in different tectonic settings represents, on the contrary, a genetic phylum (see also Camerlenghi and Pini, 2009) of direct relationships between tectonic events as primary triggering mechanisms and olistostromes. Hence, olistostromes can be interpreted as fundamental markers of tectonic events (Fig. 14), and their study can provide a powerful tool for basin analysis at various scales.

The recurrence interval of olistostromes in the geological record may be unrevealed with varying degrees of accuracy, based on the well-constrained timing of olistostrome emplacement, subsequent 
tectonic deformation events, and metamorphic history of the depositional environment of

olistostromes. Although the emplacement of an each single gravitational body is an instantaneous and

\section{Concluding remarks}

In this comparative synthesis we have examined the occurrence and the internal structure of different types of olistostromes and olistostromal deposits in various orogenic belts (with a focus on the Circum-Mediterranean, Circum-Pacific and Appalachian regions), and have addressed some of the long-lasting "olistostrome debates". This study shows that different types of olistostrome and their characteristic features are closely related to the specific tectonic settings of their formation. The systematic documentation of their blocks-in-matrix fabric, the nature and compositions of their blocks, and the lithologies, compositions and grain sizes of their matrix provide critical information on different types of deformation processes that these chaotic deposits experienced during and after their emplacement. In particular, their lithological makeup presents key evidence for determining the internal architecture of exhumed subduction-accretion complexes. Rearrangement of sediment delivery mechanisms and the types and volumes of material entering into accretionary wedges and subduction channels may vary significantly during discrete evolutionary phases and in specific parts of an accretionary wedge. 
Olistostromes commonly represent complex gravitational bodies, consisting of different parts; they do not exclusively represent the products of a single depositional event. Their internal structure reflects a close superposition in space and time of different gravitational bodies, forming masstransport complexes that are comparable in size with those observed in modern submarine settings. However, in contrast to some of the modern examples in which submarine landslides are mainly associated with gravitational instability along passive margins, ancient olistostromes are mainly preserved in the geological record of active margin settings. This phenomenon is largely due to their nature and composition, to the physiography of the depositional setting, and to downslope transformation mechanisms related to long run-out distances. Slide masses may reach extraordinary distances of translation from the source area (tens to hundreds of kilometers) that may not be evident from their internal fabric and compositions. This apparent discrepancy may stem from the combination of hydroplaning and undrained simple-pure shearing mechanisms, which occur during downslope translation at the base of and inside the gravitational body, respectively. Detailed characterization of a chaotic deposition through the use of sedimentological and structural nomenclature and terminology may be exceedingly hard to do in modern mass-transport deposits due to the limited resolution of the geophysical methods. Thus, a multiscale structural analysis, supported by sedimentological and stratigraphic observations, carried on continuous three-dimensional on-land outcrops, is commonly needed to document thoroughly the effects of strain partitioning caused by differential movements within a slide mass (Ogata et al., 2016).

Olistostromes are critical geological bodies to examine carefully in studying ancient orogenic belts and exhumed subduction-accretion complexes with a history of multi-stage deformational events. They provide excellent markers for tectonic and climatic events, and their ages and structures can be used effectively for basin analysis and modeling. Careful documentation and understanding of the overall architecture of olistostromes, their meso- to map-scale internal structures, and the mechanisms of their downslope deformation and emplacement are highly important and relevant for better understanding of modern submarine landslides and potential geohazards associated with them. 


\section{Acknowledgements}

We thank Editor M. Santosh and T. Horscroft (Elsevier) for inviting us to contribute this Focus Paper to 1807 11 1808 
Alonso, J.L., Gallastegui, J., García-Sansegundo, J., Farias, P., Rodrìguez Fernández, L.R., Ramos, V.A., 2008. Extensional tectonics and gravitational collapse in an Ordovician passive margin: the Western Argentine Precordillera. Gondwana Research 13, 204-215.

Alonso, J.L., Marcos, A., Suàrez, A., 2006. Structure and organization of the Porma mélange: progressive denudation of a submarine nappe toe by gravitational collapse. American Journal of Science 306, 32-65.

Alonso, J.L., Marcos, A., Villa, E., Suarez, A., Merino-Tomé, O.A., Fernandez, L.P., 2015. Mélanges and other types of block-in-matrix formations in the Cantabrian Zone (Variscan Orogen, northwest Spain): origin and significance. International Geology Review 57, 5-8, 563-580.

Alves, T., 2015. Submarine slide blocks and associated soft-sediment deformation in deep-water basins. A review. Marine and Petroleum Geology 67, 262-285. doi:10.1016/j.marpetgeo.2015.05.010

Amerman, R., Trudgill, B., Nelson, E.P., Pyles, D.R., 2009. 4-D distribution of deepwater masstransport deposits (Late Cretaceous Gosau Subgroup, Muttekopg Area, Northern Calcareous Alps, Austria): implications for syndepositional structural reconstruction. AAPG Datapages. Search and Discovery Article \#30108.

Anma, R., Ogawa, Y., Moore, G., Kawamura, K., Sasaki, T., Kawakami, S., Dilek, Y., Michiguchi, Y., Endo, R., Akaiwa, S., and YK99-09, YK00-08, YK05-08 \& YK06-02 Shipboard Science Parties, 2011 . Structural profile and development of accretionary complex in the Nankai trough, off Kii peninsula, Southwest Japan: results of submersible studies. In: Ogawa, Y., Anma, R. and Dilek, Y. (Eds.), Accretionary Prisms and Convergent Margin Tectonics in the Northwest Pacific Basin, v. 8, 169-196.Springer Science, Dordrecht, The Netherlands. DOI: 10.1007/978-90-481-8885-7_8.

Aoya, M., Tsuboi, M., Wallis, S.R., 2006. Origin of eclogitic metagabbro mass in the Sambagawa belt: geological and geochemical contraings. Lithos 89, 107-134.

Bailey, E.B., McCallien, W.J., 1950. The Ankara mélange and the Anatolian thrust. Nature 166, 938943.

Bailey, E.B., McCallien, W.J., 1953. Serpentinite lavas, the Ankara mélange and the Anatolian thrust. Philosophical Transaction of the Royal Society of Edinburgh 62, 11, 403-442.

Bailey, R.H., Skehan, J.W., Dreier, R.B., Webster, M.J., 1989. Olistostromes of the Avalonian terrane of southeastern New England. In: Horton, J.W., Jr., and Rast, N. (Eds.), Mélanges and olistostromes of the Appalachians. Geological Society of America Special Paper 228, 93-112.

Balestro, G., Festa, A., Dilek, Y., Tartarotti, P., 2015a. Pre-Alpine Extensional Tectonics of a Peridotite-Localized Oceanic Core Complex in the Late Jurassic, High-Pressure Monviso ophiolite (Western Alps). Episodes 38 (4), 266-282. Doi: 10.18814/epiiugs/2015/v38i4/82421.

Balestro, G., Festa, A., Tartarotti, P., 2015b. Tectonic significance of different block-in-matrix structures in exhumed converget plate margins: examples from oceanic and continental HP rocks in Inner Western Alps (northwest Italy). International Geology Review 57, 5-8, 581-605. 
Balestro, G., Lombardo, B., Vaggelli, G., Borghi, A., Festa, A., Gattiglio, M., 2014. Tectonostratigraphy of the Northern Monviso Meta-ophiolite Complex (Western Alps). Italian Journal of Geosciences 133 (3), 409-426. Doi: 10.3301/IJG.2014.13

Banchig, A.L.., 1995. Evolución del margin continental Cámbrico-Ordovícico de la Sierra del Tontal entre el río San Juan y Los Sombreros, San Juan. Unpublished PhD thesis, Universidad Nacional de San Juan, Argentina, 202 pp.

Barber, T., 2013. Mud diapirism: The origin of mélanges: Cautionary tales from Indonesia. Journal of Asian Earth Sciences 76, 428-438.

Barber, A.J., Tjokrosapoetro, S., Charlton, T.R., 1986. Mud volcanoes, shale diapirs, wrench faults and mélanges in accretionary complexes, Eastern Indonesia. American Association of Petroleum Geologists Bulletin 70, 1729-1741.

Behr, H.J., Engel, W., Franke, W., 1982. Varisican wildflysch and nappe tectonics in the Saxothuringian zone (northeast Bavaria, west Germany). American Journal of Science 282, 1438-1470.

Bernoulli, D., 2001. Mesozoic-Tertiary carbonate platforms, slope and basins of the external Appennines and Sicily. In: Vai, G.B., Martini, I.P. (Eds.), Anatomy of an Orogen: the Appennines and Adjacent Mediterranean Basins. Kluwer Academic Publishers, Great Britain, 307-325.

Berkland, J.O., Raymond, L.A., Kramer, J.C., Moores, E.M., O'Day, M., 1972. What is Franciscan? American Association of Petroleum Geologists Bulletin 56, 2295-2302.

Berry, W.B.N., 1962. Stratigraphy, zonation, and age of the Schaghticoke, Deep kill, and Normanskill shales, eastern New York. Geological Society of America Bulletin 73, 695-718.

Bertotti, G., Elter, P., Marroni, M., Meccheri, M., Santi, R., 1986. Le argilliti a blocchi di M. Veri: considerazioni sulla evoluzione tettonica del Bacino Ligure nel Cretaceo superiore. Ofioliti 11(3), 193-220.

Bettelli, G., Bonazzi, U., Fazzini, P., Panini, F., 1989. Schema introduttivo alla geologia delle Epiliguridi dell'Appennino modenese e delle aree limitrofe. Memorie Della Società Geologica Italiana 39, 215-244.

Bettelli, G., Conti, S., Panini, F., 1994. Brecce poligeniche a matrice argillosa alla base della successione Epiligure della Coltre della Val Marecchia (Appennino tosco-marchigiano): implicazioni tettoniche. Atti Ticinesi di Scienze della Terra 37, 111-131.

Bettelli, G., Panini, F., 1985. II mélange sedimentario della Val Tiepido (Appennino modenese)composizione litologica, distribuzione areale e posizione stratigrafica. Atti della Società dei Naturalisti e Matematici di Modena 115, 91-106.

Bettelli, G., Panini, F., 1989. I mélanges dell'Appennino Settentrionale dal T. Tersinaro al T. Sillaro. Memorie della Società Geologica Italiana 39, 187-214.

Bird, J.M., 1963. Sedimentary structures in the Taconic sequence rocks of the southern Taconic region. In: Guidebook for field trip three: Stratigraphy, structure, sedimentation and paleontology of the southern Taconic region, eastern New York. Geological Society of America Meeting 1963, Albany, NY, 5-21. 
Blome, C.D., Nestell, M.K., 1991. Evolution of a Permo-Triassic sedimentary mélange, Grindstone terrane, east-central Oregon. Geological Society of America Bulletin 103, 10, 1280-1296.

Boccaletti, M., Bortolotti, V., Sagri, M., 1966. Ricerche sulle ofioliti delle Catene Alpine I. Osservazioni sull'Ankara Melange nella zona di Ankara. Bollettino della Società Geologica Italiana 85, 485508.

Böhm, F., Dommergues, J.-L., Meister, C., 1995. Breccias of the Adnet Formation: Indicators of a MidLiassic tectonic event in the Northern Calcareous Alps (Salzburg/Austria). Geologische Rundschau 84, 272-286

Bortolotti, V., Carras, N., Chiari, M., Fazzuoli, M., Marcucci, M., Photiades, A., Principi, G., 2003. The Argolis Peninsula in the paleogeographic and geodynamic frame of the Hellenides. Ofioliti 28, 79-94.

Bortolotti, V., Chiari, M., Marroni, M., Pandolfi, L., Principi, G., Saccani, E., 2013. Geodynamic evolution of ophiolites from Albania and Greece (Dinaric-Hellenic belt): one, two, or more oceanic basins? International Journal of Earth Sciences 102, 783-811.

Bortolotti, V., Kodra, A., Marroni, M., Mustafa, F., Pandolfi, L., Principi, G., Saccani, E., 1996. Geology and petrology of the ophiolitic sequences in the Mirdita region, northern Albania. Ofioliti 21, 3-20

Bortolotti, V., Principi, G., and Treves, B., 2001. Ophiolites, Ligurides and the tectonic evolution from spreading to convergence of a Mesozoic Western Tethys segment. In: Vai,G.B., and Martini, I.P. (Eds.), Anatomy of an orogen: The Appennines and adjacent mediterranean basins. Great Britain, Kluwer Academic Publishers, 151-164.

Bosellini, A., 1998. Scalloped versus faulted carbonate margins and the origin of basinal megabreccias. Memorie della Società Geologica Italiana 53, 63-74.

Bosworth, W., 1989. Mélange fabrics in the unmetamorphosed external terranes of the northern Appalachians. In: Horton Jr., J.W., Rast, N. (Eds.), Mélanges and olistostromes of the Appalachians. Geological Society of America Special Papers 228, 65-91.

Bosworth, W., Vollmer, F.W., 1981. Structures of the medial Ordovician Flysch of Eeastern New York: deformation of synorogenic deposits in an overthrust environment. Journal of Geology 89, 551568 .

Brandon, M.T., 1989. Deformational styles in a sequence of olistostromal mélanges, Pacific Rim Complex, western Vancouver Island, Canada. Geological Society of America Bulletin 101, 1520-1542.

Bugge, T., Belderson, R.H., Kenyon, N.H., 1988. The Storegga slide: Philosophical Transaction of the Royal Society of London 325, 357-388.

Burg, J.P., Bernoulli, D., Smit, J., Dolati, A., Bahroudi, A., 2008. A giant catastrophic mud and debris flow in the Miocene Makran. Terra Nova 20, 181-193.

Burkhard, M., 1988, L'Helvétique de la bordure occidentale du massif de l'Aar (évolution tectonique et métamorphique). Eclogae Geologicae Helvetiae 81, 63-114. 
Callot, P., Sempere, T., Odonne, F., Robert, E., 2008. Giant submarine collapse of a carbonate platformat the Turonian-Coniacian transition:The Ayabacas Formation, southern Peru. Basin Research 20, 333-357.

Calvès, G., Huuse, M., Clift, P.D., Brusset, S., 2015. Giant fossil mass wasting off the coast of West India: the Nataraja submarine slide. Earth and Planetary Science Letters, 432, 265-272.

Camerlenghi, A., Pini, G.A., 2009. Mud volcanoes, olistostromes and Argille scagliose in the Mediterranean region. Sedimentology 56, 319-365.

Canals, M., Lastras, G., Urgeles, R., Casamor, J.L., Mienert, J., Cattaneo, A., De Batist, M., Haflidason, H., Imbo, Y., Laberg, J.S., Locat, J., Long, D., Longva, O., Masson, D.G., Sultan, N., Trincardi, F., Bryn, P., 2004. Slope failure dynamics and impacts from seafloor and shallow subseafloor geophysical data: an overview. Marine Geology 213, 9-72.

Castellarin, A., 1972. Evoluzione paleotettonica sin-sedimentaria del limite tra "piattaforma veneta" e "bacino lombardo", a Nord di Riva del Garda. Giornale di Geologia 2, 38, 11-212.

Catanzariti, R., Ellero, A., Cöncüoglu, M.C., Marroni, M., Ottria, M., Pandolfi, L., 2013. The Tarakli Flysch in the Boyali area (Sakarya Terrane, northern Turkey): Implications for the tectonic history of the IntraPontide suture zone. C.R. Geoscience 345, 454-461.

Cecca, F., Cresta, S., Giovagnoli, M.C., Manni, R., Mariotti, N., Nicosia, U., Santantonio, M., 1981. Tithonian 'Ammonitico Rosso' near Bolognola (Marche-Central Apennines): A shallow nodular limestone. In: Farinacei, A., and Elmi, S. (Eds.), Rosso Ammonitico Symposium Proceedings. Roma, Edizioni Tecnoscienza, 91-112.

Clerc, C., Lagabrielle, Y.,Neumaier M., Reynaud, J-Y., de Saint Blanquat, M., 2012. Exhumation of subcontinental mantle rocks: evidence from ultramafic-bearing clastic deposits nearby the Lherz peridotite body, French Pyrenees. Bulletin de la Societè Géologique de France 183, 5, 443-459.

Clift, P., Vannucchi, P., 2004. Controls on tectonic accretion versus erosion in subduction zones: Implications for the origin and recycling of the continental crust. Reviews of Geophysics 42, 2, RG2001. doi: 2010.1029/2003RG000127.

Cloos, M., 1982. Flow melanges: numerical modeling and geologic constraints on their origin in the Franciscan subduction complex, California. Geological Society of America Bulletin 93, 330-345.

Cloos, M., 1984. Flow mélanges and the structural evolution of accretionary wedges, in Raymond, L.A., ed., Mélanges: Their Nature, Origin, and Significance. Geological Society of America Special Paper 198, 71-79. 
Codegone,G., Festa, A., Dilek, Y., 2012a. Formation of Taconic Mélanges and Broken Formations in the Hamburg Klippe, Central Appalachian Orogenic Belt, Eastern Pennsylvania. Tectonophysics 568-569, 215-229.

Codegone, G., Festa, A., Dilek, Y., Pini, G.A., 2012b. Small-scale polygenetic mélanges in the Ligurian accretionary complex, Northern Apennines, Italy, and the role of shale diapirism in superposed mélange evolution in orogenic belts. Tectonophysics 568-569, 170-184.

Collot, J.-Y., Lewis, K., Lamarche, G., Lallemand, S., 2001. The giant Ruatoria debris avalanche on the northern Hikurangi margin, New Zealand: result of oblique seamount subduction. Journal of Geophysical Research 106, 9, 19271-19297.

Conti, S., Fontana, D., 2011. Possible Relationships between Seep Carbonates and Gas Hydrates in the Miocene of the Northern Apennines. Journal of Geological Research, Volume 2011, Article ID 920727. doi:10.1155/2011/920727

Contreras-Reyes, Volker, D., Bialas, J., Moscoso, E., Grevemeyer, I., 2016. Reloca Slide: an 24 km3 submarine mass-wasting event in response to over-steepening and failure of the central Chilean continental slope. Terra Nova, version of record online, DOI:10.1111/ter.12216

Cowan, D.S., 1985. Structural styles in Mesozoic and Cenozoic mélanges in the western Cordillera of North America. Geological Society of America Bulletin 96, 451-462.

Dangerfield, A., Harris, R., Sarifakioglu, E., Dilek, Y., 2011 . Tectonic evolution of the Ankara Mélange and associated Eldivan ophiolite near Hançili, central Turkey. In, Wakabayashi, J. and Dilek, Y. (Eds.), Melanges: Processes of formation and societal significance. Geological Society of America Special Paper 480, 143-169.

Debelmas, J., and Kerchkove, C., 1973, Large gravity nappes in the French-Italian and French-Swiss Alps. In: DeJong, K.A., and Scholten, R. (Eds.), Gravity and Tectonics. New York, John Willey and Sons, 189-200.

De Blasio, F.V., Elverhøi, A., Engvik, L.E., Issler, D., Gauer, P., Harbitz, C., 2006. Under-standing the high mobility of subaqueous debris flows. Norwegian Journal of Geology 86, 275-284.

Decandia, F.A., Elter, P., 1972. La "zona" ofiolitifera del Bracco nel settore compreso fra Levanto e la Val Graveglia (Appennino Ligure). Memorie della Societa Geologica Italiana 11, 503-530.

De Libero, C.M., 1998. Sedimentary vs. tectonic deformation in the "Argille Scagliose" of Mt. Modino (Northern Apennines). Giornale di Geologia 56, 143-166.

Della Valle G., Gamberi, F., Foglini, F., Tricardi, F., 2015.The Gondola Slide: A mass transport complex controlled by margin topography (South-Western Adriatic Margin, Mediterranean Sea). Marine Geology 366, 97-113.

Delteil, J., Mercier De Lepinay, B., Morgans, H.E.G., Field, B.D., 2006. Olistostromes marking tectonic events, East Coast, New Zealand: New Zealand Journal of Geology and Geophysics 49, 517531. 
Deville, E., Fudral, S., Lagabrielle, I., Marthaler, M., Sartori, M., 1992. From oceanic closure to continental collision: a synthesis of the "Schistes lustrés" metamorphic complex of the Western Alps. Geological Society of America Bulletin 104, 127-139.

Dilek, Y., 2003. Ophiolites, plumes and orogeny. In: Dilek, Y., and Robinson, P.T. (Eds.), Ophiolites in Earth History. Geological Society of London Special Publication 218, 9-19.

Dilek, Y., 2006. Collision tectonics of the Eastern Mediterranean region: Causes and consequences. Geological Society of America Special Paper 409, 1-13.

Dilek, Y., Delaloye, M., 1992. Structure of the Kizildag ophiolite, a slow-spread Cretaceous ridge segment north of the Arabian promontory. Geology 20, 19-22. DOI: 10.1130/00917613(1992)020.

Dilek, Y., Rowland, J.C., 1993. Evolution of a conjugate passive margin pair in Mesozoic southern Turkey. Tectonics 12, 954-970. Doi: 10.1029/93TC01060.

Dilek, Y., Newcomb, S., 2003. Ophiolite concept and the evolution of geological thought. Geological Society of America Special Paper 373, 504 p., The Geological Society of America, Boulder, CO 80301, USA, ISBN 0-8137-2373-6.

Dilek, Y., Furnes, H., 2011 . Ophiolite genesis and global tectonics: geochemical and tectonic fingerprinting of ancient oceanic lithosphere. The Geological Society of America Bulletin 123, 387-411, DOI: 10.1130/B30446.1.

Dilek, Y., Furnes, Y., 2014. Origins of ophiolites. Elements 10, 93-100, DOI: 10.2013/gselements.10.2.93.

Dilek, Y., Shallo, M., Furnes, H., 2005. Rift-drift, seafloor spreading, and subduction zone tectonics of Albanian ophiolites. International Geology Review 47, 147-176.

Dilek Y., Festa A., Ogawa Y., Pini G.A., 2012. Chaos and Geodynamics: Mélanges, Mélange-forming Processes and Their Significance in the Geological Record. Tectonophysics, 568-569, 1-6. DOI: 10.1016/j.tecto.2012.08.002.

Durand Delga, M., 1986. Principaux traits de la Corse Alpine et correlations avec les Alpes Ligures. Memorie della Società Geologica Italiana 28, 285-329.

Dykstra, M., 2005. Dynamics of sediment mass-transport from the shelf to the deep seas. Unpublished Ph.D. Dissertation, University of California, Santa Barbara, 159 pp.

Elter, P., Marroni, M., Molli, G., Pandolfi, L., 1991. Le caratteristiche stratigraphiche del Complesso di M. Penna/Casanova (Alta Val di Trebbia, Appennino Settentrionale). Atti Ticinensi di Scienze della Terra 34, 97-106.

Elter, P., Raggi, G., 1965, Contributo alla conoscenza dell'Apennino ligure: 1. Osservazioni preliminari sulla posizione delle ofioliti nella zona di Zignago (La Spezia); 2. Considerazioni sul problema degli olistostromi. Bollettino della Società Geologica Italiana 84, 303-322. 
Elter, P., Trevisan, L., 1973. Olistostromes in the tectonic evolution of the Northern Apennines. In: De Jong, K.A., Scholten, R. (Eds.), Gravity and tectonics. John Willey and Sons, New York, 175188.

Elverhøi, A., Breien, H., De Blasio, F.V., Harbitz, C.B., Pagliardi, M., 2010. Submarine landslides and the importance of the initial sediment composition for run-out length and final deposit. Ocean Dynamics 60, 1027-1046. Doi: 10.1007/s10236-010-0317-z

Epstein, J.B., Epstein, A.G., Bergström, S.M., 1972. Significance of Lower Ordovician exotic blocks in the Hamburg klippe, eastern Pennsylvania. Geological Survey Research 1972. USGS Professional Papers, 800-D, D29-D36.

Erickson, R., 2011. Petrology of a Franciscan olistostrome with a massive sandstone matrix: The King Ridge Road mélange at Cazadero, California. GSA Special Papers 480, 171-188. doi: $10.1130 / 2011.2480(07)$

Ernst, W.G., 1977. Mineral parageneses and plate tectonic settings of relatively high-pressure metamorphic belts: Fortschritte der Mineralogie 54, 192-222.

Escuder-Viruete, J., Suárez-Rodríguez, A., Gabites, J., Pérez-Estaún, A., 2015. The Imbert Formation of northern Hispaniola: a tectono-sedimentary record of arc-continent collision and ophiolite emplacement in the northern Caribbean subduction-accretionary prism. Solid Earth Discuss. 7, 1827-1876.

Fazzuoli, M., Ferrini, G., Pandeli, E., Sguazzoni, G., 1985. Le formazioni giurassico-mioceniche della falda toscana a nord dell'Arno: Considerazioni sull'evoluzione sedimentaria. Memorie della Società Geologica Italiana 30, 159-201.

Ferrière, J., Reynaud, J-Y., Pavlopoulos, A., Bonneau, M., Migiros, G., Chanier, F., Proust, J-N., Gardin, S., 2004. Geologic evolution and geodynamic controls of the Tertiary intramontane piggyback Meso-Hellenic basin, Greece. Bulletin de la Société Géologiques de France 175, 4, 361-381.

Festa, A., Accotto, C., Coscarelli, F., Malerba, E., Palazzin, G., 2014a. Geology of the Aventino River Valley (Eastern Majella,Central Italy). Journal of Maps 10, 4, 584-599. Doi: $10.1080 / 17445647.2014 .899524$ including a geological map at 1:25,000 scale.

Festa A., Balestro, G., Dilek Y, Tartarotti, P., 2015a. A Jurassic oceanic core complex in the highpressure Monviso ophiolite (western Alps, NW Italy). Lithosphere, 7, 646-652. Doi: 10.1130/L458.1.

Festa, A., Codegone, G., 2013. Geological map of the External Ligurian Units in western Monferrato (Tertiary Piedmont Basin, NW Italy). Journal of Maps 9, 1,84-97, including a geological map at 1:10,000 scale.

Festa, A., Codegone, G., Pini, G.A., 2012a. Polygenetic mélanges: the interplay of tectonic, sedimentary and diapiric processes in exhumed accretionary wedges. Rendiconti online della Società Geologica Italiana 22, 86-89.

Festa, A., Dilek, Y., Codegone, G., Cavagna, S., Pini, G.A., 2013. Structural anatomy of the Ligurian accretionary wedge (Monferrato, NW Italy), and evolution of superposed mélanges. Geological Society of America Bulletin 125, 9-10, 1580-1598. doi:10.1130/B30847.1 
Festa, A., Dilek, Y., Pini, G.A., Codegone, G., Ogata, K., 2012b. Mechanisms and processes of stratal disruption and mixing in the development of mélanges and broken formations: Redefining and classifying mélanges. Tectonophysics 568-569, 7-24. doi:10.1016/j.tecto.2012.05.021.

Festa, A., Dilek, Y., Gawlick, H-J, Missoni, S., 2014b. Mass-transport deposits, olistostromes and softsediment deformation in modern and ancient continental margins, and associated natural hazards. Marine Geology, Special Issue 356, 1-4. http://dx.doi.org/10.1016/j.margeo.2014.09.001

Festa, A., Fioraso, G., Bissacca, E., Petrizzo, M.R., 2015b. Geology of the Villalvernia-Varzi Line between Scrivia and Curone valleys (NW Italy). Journal of Maps 11, 1, 39-55.

Festa, A., Ogata, K., Pini, G.A., Dilek, Y., Codegone, G., 2015c. Late Oligocene - early Miocene olistostromes (sedimentary mélanges) as tectono-stratigraphic constraints to the geodynamic evolution of the exhumed Ligurian accretionary complex (Northern Apennines, NW Italy). International Geology Review 57, 5-8, 540-562.

Festa, A., Piana, F., Dela Pierre, F., Malusà, M.G., Mosca, P., Polino, R., 2005. Oligocene-Neogene kinematic constraints in the retroforeland basin of the Northwestern Alps. Rendiconti online della Società Geologica Italiana (nuova serie) 1, 107-108.

Festa, A., Pini, G.A., Dilek, Y., Codegone, G., 2010a. Mélanges and mélange-forming processes: a historical overview and new concepts. In: Dilek, Y. (Ed.), Alpine Concept in Geologylnternational Geology Review 52, 10-12, 1040-1105, http://dx.doi.org/10.1080/00206810903557704.

Festa, A., Pini, G.A., Dilek, Y., Codegone, G., Vezzani, L., Ghisetti, F., Lucente, C.C., Ogata, K., 2010b. Peri-Adriatic mélanges and their evolution in the Tethyan realm. In: Dilek, Y. (Ed.), Eastern Mediterranean geodynamics (Part II).International Geology Review 52, 4-6, 369-406, http://dx.doi.org/10.1080/00206810902949886.

Flores, G., 1955. Les résultats des études pour les recherches pétroliféres en Sicile: Discussion. In: Proceedings of the 4th World Petroleum Congress. Rome, Casa Editrice Carlo Colombo, Section $1 / \mathrm{A} / 2,121-122$.

Flores, G., 1956. The results of the studies on petroleum exploration in Sicily: Discussion. Bollettino del Servizio Geologico d'Italia 78, 46-47 (English translation of the 1955 paper).

Frisch, W., 1984. Sedimentological response to late Mesozoic subduction in the Penninic windows of the eastern Alps. Geologische Rundschau 73, 33-45.

Gamboa, D., Alves, T., Cartwright, J., Terrinha, P., 2010. MTD distribution on a 'passive' continental margin: The Espírito Santo Basin (SE Brazil) during the Palaeogene. Marine and Petroleum Geology 27, 1311-1324. doi:10.1016/j.marpetgeo.2010.05.008

Ganis, G.R., Williams, S.H., Repetski, J.E., 2001. New biostratigraphic information from the western part of the Hamburg klippe, Pennsylvania, and its significance for interpreting the depositional and tectonic history of the klippe. Geological Society of America Bulletin 113, 109-128.

Ganis, G.R., Wise, D.U., 2008. Taconic events in Pennsylvania: datable phases of a 20 m.y. orogeny. American Journal of Science 308, 167-183. 
Gansser, A., 1974. The ophiolite mélange: A world-wide problem on Tethyan examples. Eclogae Geologicae Helvetiae 67, 479-507.

Ghikas, A.C., Dilek, Y., Rassios, A.E., 2010. Structure and tectonics of sub-ophiolitic mélanges in the Western Hellenides (Greece) and implications for Ophiolite emplacement tectonics. In: Dilek, Y. (Ed.), Eastern Mediterranean geodynamics (Part II)International Geology Review 52, 423-453.

González Clavijo, E., Dias da Silva, I. F., Gutiérrez-Alonso, G., Díez Montes, A.,2016. U/Pb age of a large dacitic block locked in an Early Carboniferous synorogenic mélange in the Parautochthon of NW Iberia: New insights on the structure/sedimentation Variscan interplay. Tectonophysics, http://dx.doi.org/10.1016/j.tecto.2016.01.001.

Graziano, R., 2001. The Cretaceous megabreccias of the Gargano Promontory (Apulia, southern Italy): their stratigraphic and genetic meaning in the evolutionary framework of the Apulia Carbonate Platform. Terranova 13, 110-116.

Hampton, M.A., Lee, H.J., Locat, J., 1996. Submarine landslides. Reviews of Geophysics 34, 33-59.

Haq, B.U., Hardenbol, J., Vail, P.R., 1987. Chronology of fluctuating sea levels since the Triassic (250 million years ago to present). Science $235,1156-1167$.

Haq, B.U., Schutter, S.R., 2008. A chronology of Paleozoic sea-level changes. Science 322, 64-68.

Harbitz, C.B., Parker, G., Elverhøi, A., Marr, J.G., Mohrig, D., Harff, P.A., 2003. Hydroplaning of subaqueous debris flows and glide blocks: analytical solutions and discussions. Journal of Geophyical Research 108, B7, 2349. Doi: 10.1029/2001JB001454.

Hatcher, R.D., Jr., Bream, B.R., Merschat, A.J., 2007. Tectonic map of the southern and central Appalachians: A tale of three orogens and a complete Wilson cycle. In: Hatcher, R.D. Jr., Merschat R.D., Jr., Carlson, M.P., McBride, J.H., and Martínez Catalán, J.R. (Eds.), 4-D Framework of Continental Crust. Geological Society of America Memoir 200, 595-632.

Heck, F.R., Speed, R.C., 1987. Triassic olistostrome and shelf-basin transition on the western Great Basin: Paleogeographic implications. Geological Society of America Bulletin 99, 539-551.

Heim, A., 1948. Observaciones tectónicas en la Rinconada, Precordillera de San Juan. Buenos Aires. Secretaria de Industria y Comercio de la Nación, Dirección de Minas y Geología. Boletín 64, 44 pp.

Hernaiz Huerta, P.P., Pérez-Valera, F., Abad,M.,Monthel, J.,Diaz de Neira, A., 2012.Mélanges and olistostromes in the Puerto Plata area (northern Dominican Republic) as a record of subduction and collisional processes between the Caribbean and North-American plates. Tectonophysics 568-569, 266-281.

Hibbard, J.P., van Staal, C.R., Rankin, D.W., Williams, H., 2006. Lithotectonic map of the Appalachian orogen, Canada-United States of America. Geol. Surv. Can., Map 2096A, scale 1:1,500,000.

Hitz, B., Wakabayashi, J., 2012. Unmetamorphosed sedimentary mélange with high-pressure metamorphic blocks in a nascent forearc basin setting. Tectonophysics 568-569, 124-134. 
Hsü, K.J., 1974, Melanges and their distinction from olistostromes. In: Dott, R.H., Jr., and Shaver, R.H. (Eds.), Modern and ancient geosynclinal sedimentation: SEPM Special Publication 19, 321-333.

Hühnerbach, V., Massonì, D.G., Bohrmann, G., Bull, J.M., Weinrebe, W., 2005, Deformation and submarine landsliding caused by seamount subduction beneath the Costa Rica continental margin - new insights from high-resolution sidescan sonar data. Geological Society, London, Special Publications 244, 195-20.

Jacobi, R.D., and Mitchell, C.E., 2002. Geodynamical interpretation of a major unconformity in the Taconic Foredeep: Slide scar or onlap unconformity? Physics and Chemistry of the Earth 27, 169-201.

Jeanbourquin, P., 1994. Early deformation of Ultrahelvetic mélanges in the Helvetic nappes (Western Swiss Alps). Journal of Structural Geology 16, 10, 1367-1383. doi:10.1016/01918141(94)90003-5

Joanne, C., Lamarche, G., Collot J.-Y., 2013. Dynamics of giantmass transport in deep submarine environments: theMatakaoa Debris Flow, New Zealand. Basin Research 25, 1-18. doi: $10.1111 /$ bre.12006

Jones G, Robertson, AHF, 1991. Tectonostratigraphy and evolution of the Mesozoic Pindos ophiolite and related units, northwestern Greece. Journal of Geological Society of London 148, 267-288.

Kaufmann, F.J., 1886. Emmen- und Schlierengegenden nebst Umgebungen bis zur Brünigstrasse und Linie Lungern-Grafenort: Beiträge zur Geologische Karte der Schweiz 24, no. 1, 608 p.

Kawamura, K., Ogawa, Y., Hara, H., Anma, R., Dilek, Y., Kawakami, S., Chiyonobu, S., Mukoyoshi, H., Hirano, S., Motoyama, I., 2011. Rapid exhumation of metamorphosed sediment with gravitational collapse in an active eastern Nankai accretionary prism, Japan. . In: Ogawa, Y., Anma, R. and Dilek, Y. (Eds.), Accretionary Prisms and Convergent Margin Tectonics in the Northwest Pacific Basin, v. 8, 215-227.Springer Science, Dordrecht, The Netherlands. DOI: 10.1007/978-90-481-8885- 7_10.

Keller, M., 1999. Argentine Precordillera: sedimentary and plate tectonic history of a Laurentian crustal fragment in South America. The Geological Society of America, Special Paper 341, 131 pp

Kempf, O., and Pfiffner, A., 2004. Early tertiary evolution of the North Alpine Foreland Basin of the Swiss Alps and adjoining areas. Basin Research 16, 549-567.

King, P.R., Ilg, B.R., Arnot, M., Browne, G.H., Strachan, L.J., Crundwell, M., Helle, K., 2011. Outcrop and seismic examples of MTDs, Taranaki Basin, New Zealand. In: Shipp, R.C., Weimer, P., Posamentier, H.W., Eds., Mass-transport Deposits in Deepwater Settings. SEPM Special Pubblication 96, 311-348. Doi: 10.2110/sepmsp.096.311

Kovacs, S., 1989. Devonian olistostrome with limestone olistoliths and volcanic matrix from Strazsa Hill, Uppony Mts., northeastern Hungary. Neues Jahrbuch fuer Geologie und Palaeontologie. Monatshefte 2, 109-127.

Krastel, S., Behrmann, J-H., Volker, D., Stipp, D., Berndt, R., Urgeles, R, Chaytor J., Huhnn, K., Strasser, M., Harbitz, C.B., (Eds-), 2014. Sumabrine Mass Movements and their consequences, 
Advances in Natural and Technologial Hazards Research 37, Springer Science+Business Media B.V. 2014, 683 pp. Doi: 10.1007/978-3-319-00972-8.

Labaume, P., 1992. Evolution tectonique et sédimentaire des front de chaîne sous-marins. Exemples des Apennins du Nord, des Alpes françaises et de Sicile. Unpublished PhD thesis, University of Montpellier, $476 \mathrm{pp}$.

Lagabrielle, Y., 1994. Ophiolites of the southwestern Alps and the structure of the Tethyan oceanic lithosphere. Ofioliti 19, 413-434.

Lagabrielle, Y., Lemoine, M., 1997. Alpine, Corsican and Apennine ophiolites: The slow-spreading ridge model. C.R. Acad. Sci. Paris 325, 909-920.

Lagabrielle, Y., Polino, R., Auzende, J.M., Blanchet, R., Caby, R., Fudral, S., Lemoine, M., Mével, C., Ohnenstetter, M., Robert, D., Tricart, P., 1984. Les temoins d'une tectonique intraoceanique dans le domaine Tethysien: Analyse des rapports entre les ophiolites et leurs couvertures metasedimentaires dans la zone Piemontaise des Alpes Franco-Italiennes. Ofioliti 9, 1, 67-88.

Lagabrielle, Y., Whitechurch, H., Marcoux, J., Juteau, T., Reuber, I., Guillocheau, F., Capan, U., 1986. Obduction-related ophiolitic polymict breccias covering the ophiolites of Antalya (southwestern Turkey). Geology 14, 734-737.

Lamarche, G., Joanne, C., Collot, J-Y., 2008. Successive, large mass-transport deposits in the south Kermadec fore-arc basin, New Zealand: The Matakaoa Submarine Instability Complex. Geochemistry, Geophysics, Geosystems 9 (4), Q04001, doi: 10.1029/2007GC001843.

Lamarche, G., Mountjoy, J., Bull., S., Huble, T., Krastel, S., Lane, E., Micallef, A., Moscardelli, L., Mueller, C., Pecher, I., Woelz, S. (Eds.), 2016. Sumabrine Mass Movements and their consequences, Advances in Natural and Technologial Hazards Research 37, Springer Science+Business Media B.V. 2016, 621 pp. Doi: 10.1007/978-3-319-20979-1.

Lash, G.G., 1985. Accretion-related deformation of an ancient (early Paleozoic) trench-fill deposit, central Appalachian orogen. Geological Society of America Bulletin 96, 1167-1178.

Lash, G.G., 1987. Diverse melanges of an ancient subduction complex. Geology 15, 652-655.

Lash, G.G., Drake Jr., A.A., 1984. The Richmond and Greenwich Slices of the Hamburg klippe in eastern Pennsylvania-stratigraphy, sedimentology, structure, and plate tectonic implications. USGS Professional Papers 1312, 40 pp.

Lewis, K.B., Lallemand, S., Carter, L., 2004. Collapse in a Quaternary shelf basin off East Cape, New Zealand: evidence for the passage of a subducted seamount inboard of the Ruatoria giant avalanche. New Zealand Journal of Geology and Geophysics 47, 415-429.

Liu, F., Yang, J.-S., Dilek, Y., Xu, X.-Z., Xu, X.-Z, Liang, F.-H., Chen, S.-Y., Lian, D.-Y., 2015. Geochronology and geochemistry of the basaltic lavas in the Dongbo and Purang ophiolites of the Yarlung-Zangbo Suture zone : Plume-influenced continental margin-type oceanic lithosphere in southern Tibet. Gondwana Research 27, 701-718. DOI: 10.1016/j.gr.2013.08.002. 
Lucente, C.C., Pini, G.A., 2003. Anatomy and emplacement mechanism of a large submarine slide within the Miocene foredeep in the Northern Apennines, Italy: A field perspective. American Journal of Science 303, 565-602.

Lucente, C.C., Pini, G.A., 2008. Basin-wide mass-wasting complexes as markers of the OligoMiocene foredeep-accretionary wedge evolution in the Northern Apennines, Italy. Basin Research 20, 49-71.

Marroni, M., Meneghini, F., Pandolfi, L., 2010, Anatomy of the Ligure-Piemontese subduction system: evidence from Late Cretaceous-Middle Eocene convergent margin deposits in the Northern Apennines, Italy. International Geology Review 52, 1160-1192. doi:10.1080/00206810903545493

Marroni, M., Pandolfi, L., 2001. Debris flow and slide deposits at the top of the Internal liguride ophiolitic sequence, Northern Apennines, Italy: a record of frontal tectonic erosion in a fossil accretionary wedge. Island Arc 10, 9-21.

Martinez Catalan, J., Arenas, R., Diaz Garcia, F., Abati, J., 1997. Varisican accretionary complex of northwest Iberia: Terrane correlation and succession of tectonothermal events. Geology 25, 1103-1106.

Martín-Merino, G., Fernández, L.P., Colmenero, J.R., Bahamonde, J.R., 2014. Mass-transport deposits in a Variscan wedge-top foreland basin (Pisuerga area, Cantabrian Zone, NW Spain). Marine Geology 356, 71-87.

Masson, H., Bussy, F., Eichenberger, M., Giroud, N., Meilhac, C., Presniakov, S., 2008, Early Carboniferous age of the Versoyen ophiolites and consequences: Non-existence of a 'Valais ocean' (Lower Penninic, Western Alps). Bulletin de la Société Géologiques de France 179, 4, 337-355.

McAdoo, B., Pratson, L., and Orange, D., 2000. Submarine landslide geomorphology, US continental slope: Marine Geology 169, 103-136.

Macdonald, D.I.M., Moncrieff, A.C.M., Butterworth, P.J., 1993. Giant slide deposits from a Mesozoic fore-arc basin, Alexander Island, Antarctica. Geology 21 (11), 1047-1050

Malavieille, J., Molli, G., Genti, M., Dominguez, S., Beyssac, O., Taboada, A., Vitale-Brovarone, A., Chia-Yu, Lu., Chih-Tung, C. 2016. Formation of ophiolite-bearing tectono-sedimentary mélanges in accretionary wedges by gravity driven submarine erosion: Insights from analog models and case studies. Journal of Geodynamics, in press online. http://dx.doi.org/doi:10.1016/j.jog.2016.05.008

Mattioni, L., Tondi, E., Shiner, P., Renda, P., Vitale, S., Cello, G., 2006. The Argille Varicolori unit in Lucania (Italy): a record of tectonic offscraping and gravity sliding in the Mesozoic-Tertiary Lagonegro Basin, southern Apennines. In: Moratti, G., and Chalouan, A. (Eds.), Tectonics of the Western Mediterranean and North Africa. Geological Society, London, Special Publications 262, 277-288.

Medialtea, T., Vegas, R., Somoza, L., Vázquez, J.T., Maldonado, A., Díaz-del-Río, V., Mestro, A., Córdoba, D., Fernández-Puga, M.C., 2004. Structure and evolution of the "Olistostrome" complex of the Gibraltar Arc in the Guld of Cádiz (eastern Central Atlantic): evidence from two long seismic cross-sections. Marine Geology 209, 173-198. 
Michard, A., Chopin, C., Goffé, B., 1991. Obduction versus subduction and collision in the Oman case and in the other Tethyan setting. In: Peters, TJ., Nicolas, A., Coleman, R.G. (eds) Ophiolite genesis and evolution of the oceanic lithosphere. Petroleum Struct Geol 5:447-467

Michard, A., Yazidi, A., Benziane, F., Hollard, H., Willefert, S., 1982. Foreland thrusts and olistostromes on the presaharian margin of the variscan orogen, Morocco. Geology 10, 253-256.

Mienert, J., Berndt, C., Laberg, J.S., Vorren, T., 2003, Slope instability of continental margins. In: Wefer, G., Billet, D., Hebbeln, D., Jørgensen, B.B., Schlüter, M., van Weering, T. (Eds.), Ocean margin systems. Berlin, Springer, 179-193.

Moore, D.G., Curray, J.R., Emmel, F.J., 1976. Large submarine slide (olistostrome) associated with Sunda Arc subduction zone, northeast Indian Ocean. Marine Geology 21, 211-226.

Moscardelli, L., Woods, L., 2016. Morphometry of mass-transport deposits as a predictive tool. Geological Society of America Bulletin 128 (1-2), 47-80.

Mosher, D.C., Shipp, R.C., Moscardelli, L., Chaytor, J.D., Baxter, C.D.P., Lee, H.J, Urgeles, R. (Eds.), 2010. Sumabrine Mass Movements and their consequences, Advances in Natural and Technologial Hazards Research 28, Springer Science+Business Media B.V. 2010, 786 pp. Doi: 10.1007/978-90-481-3071-9.

Mountjoy, J.J., Micallef, A., 2012. Polyphase emplacement of a $30 \mathrm{~km} 3$ blocky debris avalanche and its role in slope-gully development. In: Yamada, Y., Kawamura, K., Ikehara, K., Ogawa, Y., Urgeles, R., Mosher, D., Chaytor, J., Strasser, M. (Eds.), Submarine Mass Movements and Their Consequences. Advances in Natural and Technological Hazards Research, Springer Netherlands, pp. 213-222.

Mutti, E., Bernoulli, D., Ricci Lucchi, F., Tinterri, R., 2009. Turbidites and turbidity currents from Alpine 'flysch' to the exploration of continental margins: Sedimentology 56, 267-318.

Mutti, E., Carminatti, M., Moreira, J.L.P., Grassi, A.A., 2006. Chaotic Deposits: examples from the Brazilian offshore and ,from outcrop studies in the Spanish Pyrenees and Northern Apennines, Italy. American Association Petroleum Geologists Annual Meeting, April 9-12, Houston, Texas.

Mutti, E., Tinterri, R., Remacha, E., Mavilla, N., Angella, S., Fava, L., 1999. An introduction to the analysis of ancient turbidite basins from an outcrop perspective. AAPG Course Note 39, 93.

Naylor, M.A., 1982. The Casanova Complex of the Northern Apennines: A mélange formed on a distal passive continental margin. Journal of Structural Geology 4, 1-18.

Naylor, M.A., Harle, T., 1976, Palaeogeographic significance of rocks and structures beneath the Vourinos ophiolite, northern Greece: Journal of the Geological Society, London 132, 667-676.

Nielsen, T., Kuijpers, A. 2004. Geohazard studies offshore the Faroe Islands: slope instability, bottom currents and sub-seabed sediment mobilisation. Geological Survey of Denmark and Greenland Bulletin 4, 57-60.

Nisbet, E.G, Piper, D.J.W., 1998. Gian submarine landslides. Nature 392, 329-330. 
Nissen, S. E., Haskell, N. L., Steiner, C. T., Coterill, K. L. 1999. Debris flow outrunner blocks, glide tracks, and pressure ridges identified on the Nigerian continental slope using 3-D seismic coherency. The Leading Edge, Society of Exploration Geophysicists 18, 550-561.

Ogata, K., Mountjoy, J.J., Pini, G.A., Festa, A., Tinterri, E., 2014a. Shear zone liquefaction in mass transport deposit emplacement: A multi-scale integration of seismic reflection and outcrop data. Marine Geology, Special Issue 356, 50-64. Doi: 10.1016/j.margeo.2014.05.001

Ogata, K., Pini, G.A., Carè, D., Zélic, M., Dellisanti, F., 2012a. Progressive development of block-inmatrix fabric in a shale-dominated shear zone: Insights from the Bobbio Tectonic Window (Northern Apennines, Italy). Tectonics 31, TC1003, http://dx.doi.org/10.1029/2011TC002924.

Ogata, K., Pini, G.A., Festa, A., Pogačnik, Ž., Lucente, C.C., 2016. Meso-scale kinematic indicators in exhumed mass transport deposits: definitions and implications. In: G. Lamarche et al. (Eds.), Submarine Mass Movements and their Consequences, Advances in Natural and Technological Hazards Research 41, 461-468.

Ogata, K., Pogačnik, Ž. , Pini, G.A., Tunis, G., Festa, A., Camerlenghi, A., Rebesco, M., 2014b. The carbonate mass transport deposits of the Paleogene Julian-Slovenian Basin (Italy/Slovenia): internal anatomy and inferred genetic processes. Marine Geology 356, 88-110.

Ogata, K., Tinterri, R., Pini, G.A., Mutti, E., 2012b. Mass transport-related stratal disruption within sedimentary mélanges: Examples from the northern Apennines (Italy) and south-central Pyrenees (Spain). Tectonophysics 568-569, 185-199.

Ogata, K., Tinterri, R., Pini, G.A., Mutti, E., 2012c. The Specchio Unit (Northern Apennines, Italy): an ancient mass transport complex originated from near-coastal areas in an intra-slope setting. In: Yamada, Y., et al. (Eds.), Submarine mass movements and their consequences. : Advances in natural and technological hazards research, 31. Springer Science+Business Media B.V., pp. 595-605.

Ogniben, L., 1953. "Argille scagliose" ed "argille brecciate" in Sicilia. Bollettino del Servizio Geologico d'Italia 75, 279-289.

Okay, A.I., İşintek, I., Altıner, D., Özkan-Altıner, S., Okay, N., 2012. An olistostrome-mélange belt formed along a suture: Bornova Flysch zone, western Turkey. Tectonophysics 568-569, 282295. doi:10.1016/j.tecto.2012.01.007

Omosanya, K.O., Alves, T.M., 2012. A 3-dimensional seismic method to assess the provenance of Mass-Transport Deposits (MTDs) on salt-rich continental slopes (Espírito Santo Basin, SE Brazil). Marine and Petroleum Geology 44, 223-239. doi:10.1016/j.marpetgeo.2013.02.006

Ortiz-Karpf, A., Hodgson, D.M., Jackson, C.A.-L., McCaffrey, W.D., 2016. Mass-Transport Complexes as Markers of Deep-Water Fold-and-Thrust Belt Evolution: Insights from the Southern Magdalena Fan, Offshore Colombia. Basin Research, in press, doi: 10.1111/bre.12208

Ortner, H., 2001. Growing folds and sedimentation of the Gosau Group, Muttekopf, Northern Calcareous Alps, Austria. International Journal of Earth Sciences 90, 727-739.

Osozawa, S., Pavlis, T., Flowers, M.F.J., 2011. Sedimentary block-in-matrix fabric affected by tectonic shear, Miocene Nabae complex, Japan. In: Wakabayashi, J., Dilek, Y. (Eds.), Mélanges: 
Processes of Formation and Societal Significance. Geological Society of America Special Papers 480, 189-206, http://dx.doi.org/10.1130/2011.2480(08).

Page, B.M., 1962. Geology South and East of Paso della Cisa, Northern Apennines: Bollettino della Società Geologica Italiana 81, 147-194

Page, B.M., Suppe, J., 1981. The Pliocene Lichi melange of Taiwan: its plate-tectonic and olistostromal origin. American Journal of Science 281, 193-227.

Panini, F., Fioroni, C., Fregni, P., Bonacci, M., 2002. Le rocce caotiche dell'Oltrepo Pavese: note illustrative della Carta Geologica dell'Appennino vogherese tra Borgo Priolo e Ruino. Atti Ticinensi di Scienze della Terra 43, 83-109.

Papani, G., 1963. Su un olistostroma di 'Argille Scagliose' intercalato nella serie oligo-miocenica del subappennino reggiano (nota preliminare). Bollettino della Società Geologica Italiana 82, 3, 195-202.

Parker, G., 2000, Hydroplaning outrunner blocks from auto-acephalated subaqueous debris flows and landslides. Eos Trans. AGU, 81(48), Fall Meet. Suppl., Abstract OS51D-08.

Parlak, O., Robertson, A., 2004. The ophiolite-related Mersin Melange, southern Turkey: Its role in the tectonic-sedimentary setting of Tethys in the Eastern Mediterranean region. Geological Magazine 141, 3, 257-286.

Passchier, C.W., Trouw, R.A., 2005. Microtectonics. Springer, Berlin Heidelberg New York, 365 pp.

Payros, A., Pujalte, V., Orue-Etxebarria, X., 1999. The South Pyrenean Eocene carbonate megabreccias revisited: new interpretation based on evidence from the Pamplona Basin. Sedimentary Geology 125, 165-194.

Pini, G.A., 1999. Tectonosomes and olistostromes in the Argille Scagliose of the Northern Apennines, Italy. Geological Society of America Special Papers 335, 73 pp.

Pini, G.A., Camerlenghi, A., Ogata, K., Cowan, D.S., Urgeles, R., 2010a. Olistostromes and olistoliths: a historical review and modern perspectives. Geologica Balcanica 39, 1-2, 309-310.

Pini, G.A., Camerlenghi, A., Ogata, K., Festa, A., Codegone G., Lucente, C.C., Urgeles, R., 2010b. Olistostromes, mélanges and mass-transport deposits. Rendiconti online della Società Geologica Italiana 11, 445-446.

Pini, G.A., Lucente, C.C., Cowan, D.S., De Libero, C.M., Dellisanti, F., Landuzzi, A., Negri, A., Tateo, F., Del Castello, M., Morrone, M., Cantelli, L., 2004. The role of olistostromes and argille scagliose in the structural evolution of the Northern Apennines. In: Guerrieri, L., Rischia, I., and Serva, L., (Eds.), Field Trip Guidebooks, 32nd IGC Florence 20-28 August 2004. Memorie Descrittive della Carta Geologica d'Italia 63, B13, 1-40.

Pini, G.A., Ogata, K., Camerlenghi, A., Festa, A., Lucente, C.C., Codegone, G., 2012. Sedimentary mélanges and fossil mass-transport complexes: a key for better understanding submarine mass movements? In: Yamada, Y., et al. (Eds.), Submarine mass movements and their consequences. : Advances in natural and technological hazards research 31. Springer Science+Business Media B.V., 585-594. 
Platt, J.P., 2015. Origin of Franciscan blueschist-bearing mélange at San Simeon, central California coast. International Geology Review 57, 5-8, 843-868.

Polino, R., 1984. Les seriés océaniques du haut Val de Suse (Alpes Cottiennes): analyse des couvertures sédimentaires. Ofioliti 9, 3, 547-554.

Prior, D.B., Bornhold, B.D., Johns, M.W., 1984. Depositional characteristics of a submarine debris flow. Journal of Geology 92, 707-727.

Prior, D.B., Doyle, E.H., Neurauter, T., 1987. The Currituck slide, Mid-Atlantic continental sloperevisited. Marine Geology 73, 25-45.

Quintana, L., Pulgar, J.A., Alonso, J.L., 2015. Displacement transfer from borders to interiors of a plate: a crustal transect of Iberia. Tectonophysics $663,378-398$.

Rast, N., Horton Jr., J.W., 1989. Melanges and olistostromes in the Appalachians of the United States and mainland Canada: an assessment. In: Horton Jr., J.W., Rast, N.(Eds.), Mélanges and olistostromes of the AppalachiansGeological Society of America Special Papers 228, 1-16.

Rast, N., Kohles, K.M., 1986. The origin of the Ocoee Supergroup. American Journal of Science 286, 593-616.

Raymond, L.A., 1984. Classification of melanges. In: Raymond, L.A. (Ed.), Melanges: Their nature, origin and significance. Boulder, ColoradoGeological Society of America Special Papers 198, 720.

Raymond, L.A., Bero, D., 2015. Sandstone-matrix mélanges, architectural subdivision, and geologic history of accretionary complexes: a sedimentological and structural perspective from the Franciscan Complex of Sonoma and Marin counties, California, USA. Geosphere 11, 4, 1-34. doi:10.1130/GES01137.1

Raymond, L.A., Terranova, T., 1984. The melange problem - a review. Geological Society of America Special Paper 198, 1-3.

Reed, J.C., Jr., Wheeler, J.O., Tucholke, B.E., 2005. Geologic Map of North America-Perspectives and explanation. Boulder, Colorado, Geological Society of America, Decade of North American Geology, 1-28.

Remitti, F., Vannucchi, P., Bettelli, G., Fantoni, L., Panini, F., Vescovi, P., 2011. Tectonic and sedimentary evolution of the frontal part of an ancient subduction complex at the transition from accretion to erosion: The case of the Ligurian wedge of the northern Apennines, Italy. Geological Society of America Bulletin 123, 51-70.

Rigo de Righi, M., 1956. Olistostromi neogenici in Sicilia. Bollettino della Società Geologica Italiana $75,185-215$.

Root, S.I., MacLachlan, D.B., 1978. Western limit of Taconic allochthons in Pennsylvania. Geological Society of America Bulletin 89, 1515-1528.

Rowe, C.D., Moore, J.C., Remitti, F., and the IODP (International Ocean Discovery Program) Expedition 343/343T Scientists, 2013. The thickness of subduction plate boundary faults from the seafloor into the seismogenic zone. Geology 41, 991-994, doi: $10.1130 / G 34556.1$. 
Ruh, J.B., 2016. Submarine landslides caused by seamounts entering accretionary wedge systems. Terra Nova, first on-line, doi: 10.1111/ter.12204

Salamon, M., Königshof, P., 2010. Middle Devonian olistostromes in the Rheno-Hercynian zone (Rheinisches Schiefergebirge) - An indication of back arc rifting on the southern shelf of Laurussia. Gondwana Research 17, 281-291.

Saleeby, J, 1979. Kaweah serpeninite mélange, southwest Sierra Nevada footwhills, California. Geological Society of America Bulletin 90, 29-46.

Sarifakioglu, E., Dilek, Y., and Winchester, J.A., 2012. Late Cretaceous Subduction Initiation and Paleocene - Eocene Slab Breakoff Magmatism in South-Central Anatolia, Turkey. International Geology Review 55, 66-87.

Sarifakioglu, E., Dilek, Y., Sevin, M., 2014. Jurassic - Paleogene intra-oceanic magmatic evolution of the Ankara Mélange, North Central Anatolia, Turkey. Solid Earth 5, 77108, Doi:10.5194/se-5-77-2014.

Scherba, I.G., 1989. Stage and phases of formation of Cenozoic olistostromes in the Alpine Fold Belt. In: G. Leonov, Y., and Khain, V.E. (Eds.), Global Correlation of Tectonic Movements, John Wiley and Sons, New York, 49-82.

Schroetter, J-M., Tremblay, A., Bédard, J.H., Villeneuve, E. 2006. Syncollisional basin development in the Appalachian orogeny - The Saint Daniel Mélange, southern Québec, Canada. Geological Society of America Bulletin 118, 109-125.

Seely, D.R., Vail, P.R., Walton, G.G., 1974. Trench slope Model. In: Burke, C.A., and Drake, C.L. (Eds.), The Geology of Continental Margins: New York, Springer-Verlag, 249-260.

Şengör, A.M.C., 2003. The repeated rediscovery of mélanges and its implication for the possibility and the role of objective evidence in the scientific enterprise. In: Dilek, Y., Newcomb, S. (Eds.), Ophiolite concept and the evolution of geological thought. Boulder, ColoradoGeological Society of America Special Papers 373, 385-445.

Shallo, M., 1990. Ophiolitic mélange and flyschoidal sediments of the Tithonian-Lower Cretaceous in Albania. Terra Nova 2, 476-483.

Shallo, M., Dilek, Y., 2003. Development of the ideas on the origin of Albanian ophiolites. Geological Society of America Special Paper 373, 351-364.

Shanmugam, G., 2015. The landslide problem. Journal of Palaegeoography 4, 2, 109-166. Doi: 10.3724/SP.J.1261.2015.00071

Silver, E.A., Beutner, E.C., 1980. Melanges. Geology 8, 32-34.

Ślączka, A., Renda, P., Cieszkowski, M., Golonka, J., Nigro, F., 2012. Sedimentary basin evolution and olistoliths formation: the case of Carpatian and Sicilian regions. Tectonophysics 568-569, 306-319.

Smith, A.G., Woodcock, N.H., Naylor, M.A., 1979. The structural evolution of a Mesozoic continental margin, Othris Mountains, Greece. Journal of the Geological Society of London 136, 589-601. 
Snedden, J.W, Liu, C., 2010. A compilation of Phanerozoic sea-level change, coastal onlaps and recommended sequence designations. AAPG Search and discovery article \#40594.

Sobiesiak, M.S., Kneller, B., Alsop, G.I., Milana, J.P., 2016. Inclusion on substrate blocks within a mass transport deposit: a case study from Cerro Bola, Argentina. In: G. Lamarche et al. (Eds.), Submarine Mass Movements and their Consequences, Advances in Natural and Technological Hazards Research 41, 487-496.

Stevens, R. K., 1968. Taconic klippen of western Newfoundland: Canadian Geo logical Survey Paper 68-1, Part A, 8-10.

St-Julien, P., Hubert, C., 1975. Evolution of the Taconian orogen in the Québec Appalachians: American Journal of Science 275, 337-362.

Strachan, L.J., 2002. Slump-initiated and controlled syndepositional sandstone remobilization: an example from the Namurian of County Clare, Ireland. Sedimentology 49, 25-41.

Strachan, L.J., Alsop, G.I., 2006. Slump folds as estimators of paleoslope: a case study from the Fisherstreet Slump of County Clare, Ireland. Basin Research 18, 451-470.

Strasser, M., Henry, P., Kanamatsu, T., Thu, M.K., Moore, G.F. and IODP Expedition 333 Scientists, 2012. Scientific Drilling of Mass-Transport Deposits in the Nankai Accretionary Wedge: First Results from IODP Expedition 333. In: Y. Yamada et al. (eds.), Submarine Mass Movements and Their Consequences, Advances in Natural and Technological Hazards Research 31, Springer Science+Business Media B.V., 671-681. Doi: 10.1007/978-94-007-2162-3_60

Strasser, M., Moore, G.F., Kimura, G., Kopf, A.J., Underwood, M.B., Guo, J., Screaton, E.J., 2011. Slumping and mass transport deposition in the Nankai fore arc: Evidence from IODP drilling and 3-D reflection seismic data: Geochemistry: Geophysics, Geosystems 12, Q0AD13. Doi:0.1029/2010GC003431

Studer, B., 1872. Index der Petrographie und Stratigraphie der Schweiz und ihrer Umgebungen: Bern, Verlag der J. Dalp'schen Buch- und Kunstdhandlung (K. Schmid), 272 p.

Swarbick, R.E., Naylor, M.A., 1980. The Kathikas melange, SW Cyprus: late Cretaceous submarine debris flows. Sedimentology 27, 63-78.

Taira, A., Byrne, T., Ashi, J., 1992. Photographic atlas of an accretionary prism: Geological structures of the Shimanto Belt, Japan. Tokyo, Springer-Verlag and University of Tokyo Press, 124 pp.

Tartarotti, P., Festa, A., Benciolini, L., Balestro, G., 2015. Fossil mantle-sediments interface recognized in the Western Alps metaophiolites: a key to unravel the accretion mechanism of the Jurassic Tethys Ocean. Rendiconti online della Società Geologica Italiana 35, 68-71.

Tekeli, O., Erendil, M., 1986. Geology and petrology of the Kizildag ophiolite (Hatay).Bulletin of the Mineral Research and Exploration Institute, Turkey (MTA) 21, 21-37.

Torbi A., 1996. Stratigraphie et évolwtion structurale paléozoïque d'un segment de la Meseta orientale marocaine (Monts du Sud-Est d'Oujda): rôle des décrochements dans la formation de l'olistostrome intraviséen et le plutonisme tardi-hercynien. Journal of African Earth Sciences 22, 4, 549-563. 
Torelli, L., Sartori, R., Zitellini, N., 1997. The giant chaotic body in the Atlantic Ocean off Gibraltar: new results from a deep seismic reflection survey. Marine and Petroleum Geology 14, 125-138.

Tunis, G., Venturini, S., 1992. Evolution of the Southern Margin of the Julian Basin with emphasis on the megabeds and turbidites sequence of the Southern Julian Alps (NE Italy). Geologia Croatica $45,127-150$.

Urgeles, R., Camerlenghi, A., 2013. Submarine landslides of the Mediterranean Sea: Triggering mechanisms, dynamics, and frequency-magnitude distribution. Journal of Geophysical Research: Earth Surface 118, 2600-2618.

Ukar, E., 2012. Tectonic significance of low-temperature blueschist blocks in the Franciscan mélange at San Simeon, California. Tectonophysics 568-569, 154-169.

Ukar, E., Cloos, M., 2015. Magmatic origin of low-T mafic blueschist and greenstone blocks from the Franciscan mélange, San Simeon, California. Lithos 230, 17-29.

Ukar, E., Cloos, M., 2016. Graphite-schist blocks in the Franciscan Mélange, San Simeon, California: Evidence of high-P metamorphism. Journal of Metamorphic Geology 34, 191-208.

Vail, P.R., Mitchum, R.M., 1980. Global cycles of sea-level change and their role in exploration. Proceeding World Pet. Congr., 10, th $95-104$.

van der Merwe, W.C., Hodgson, D.M., Flint, S.S., 2009. Widespread syn-sedimentary deformation on a muddy deep-water basin-floor: the Vischkuil Formation (Permian), Karoo Basin, South Africa. Basin Research 21, 389-406.

Vanneste, M., Harbitz, C.B., De Blasio F.V., Glimsdal, S., Mienert, J., Elverhøi, A., 2011. HinlopenYermark Landslide, Artic Ocean - Geomorphology, landslide dynamics and tsunami simulations. In: Shipp, R.C., Weimer, P., Posamentier, H.W., Eds., Mass-transport Deposits in Deepwater Settings. SEPM Special Pubblication 96, 509-527. DOI: 10.2110/sepmsp.096.509

Vannucchi, P., Sage, F., Phipps Morgan, J., Remitti, F., Collot, J-Y., 2012. Toward a dynamic concept of the subduction channel at erosive convergent margins with implications for interpolate material transfer. Geochemistry, Geophysics, Geosystems, 13 (1), Q02003, doi:10.1029/2011GC003846

Vezzani, L., Festa, A., Ghisetti, F., 2010. Geology and Tectonic evolution of the Central-Southern Apennines, Italy. Geological Society of America Special Papaper 469, 58 pp., accompanying by a CD-ROM including the "Geological-Structural Map of the Central-Southern Apennines (Italy)" at 1:250.000 scale, Sheets 1 and 2, doi: 10.1130/2010.2469

Vollmer, F. W., 1980. Progressive deformation, fold rotation and mélange formation in Middle Ordovician flysch near Albany, New York. Geological Society of America Abstracts with Programs 12, 542-543.

Vollmer, F.W., Bosworth, W., 1984. Formation of melange in a foreland basin overthrust setting: Example from Taconic Orogen. In: Raymond, L.A. (Ed.), Melanges: Their nature, origin, and significance. Geological Society of America Special Papers 198, 53-70. 
von Gosen, W., Buggishs, W. Lehnert, O., 1995. Evolution of the Early Paleozoic mélange at the eastern margin of the Argentine Precordillera. Journal of South America Earth Sciences 8, 405424.

von Huene, R., Bourgois, J., Miller, J., Pautot, G., 1989. A large tsunamogenic landslide and debris flow along the Peru Trench. Journal of Geophysical Research 94(B2), 1703-1714, doi: 10.1029/JB094iB02p01703)

von Huene, R., Lallemand, S., 1990. Tectonic erosion along the Japan and Peru convergent margin. Geological Society of America Bulletin 102, 704-720.

von Huene, R., Ranero, C.R., Vannucchi, P., 2004. Generic model of subduction erosion. Geology 32, 913-916.

Wakabayashi, J., 2012. Subducted sedimentary serpentinite mélanges: Record of multiple burialexhumation cycles and subduction erosion. Tectonophysics 568-569, 230-247.

Wakabayashi, J., 2015. Anatomy of a subduction complex: architecture of the Franciscan Complex, California, at multiple length and time scales. International Geology Review 57, 669-743.

Wakita, K, 2015. OPS mélange: a new term for mélanges of convergent margins of the world. International Geology Review 57, 5-8, 529-539.

Weimer, P., 1989. Sequence stratigraphy of the Mississippi Fan (Plio-Pleistocene), Gulf of Mexico. Geo-Marine Letters 9, 185-272.

Weimer, P., Shipp, C., 2004. Mass transport complexes: musing on past uses and suggestions for future directions. Offshore technology conference, Paper 16752, Houston, 3-6 May 2004

Wise,D.U., Ganis,G.R., 2009. Taconic Orogeny in Pennsylvania: a 15-20 m.y. Apennine-style Ordovician event viewed from its Martic hinterland. Journal of Structural Geology 31, 887-899.

Wheeler, J. O., McFeely, P., 1991. Tectonic assemblage map of the Canadian Cordillera and adjacent parts of the United States of America. Scale 1:2.000.000. Geological Survey of Canada. Map $1712 \mathrm{~A}$.

Woodcock, N.H., 1979. The use of slump structures as palaeoslope orientation estimators. Sedimentology 26, 1, 83-99.

Yamada, Y, Kawamura, K., Ikehara, K., Ogawa, Y., Urgeles, R., Mosher, D., Chaytor, J, and Strasser, M. (Eds.), 2012, Sumabrine Mass Movements and their consequences, Advances in Natural and Technologial Hazards Research 31, Springer Science+Business Media B.V. 2012, 756 pp. Doi: 10.1007/978-94-007-2162-3

Yamamoto, Y., Nidaira, M., Ohta, Y., Ogawa, Y., 2009. Formation of chaotic rock units during primary accretion processes: examples from the Miura-Boso accretionary complex, central Japan. Island Arc 18, 496-512.

Yilmaz, P.O., Maxwell, J.C., 1984, An example of an obduction melange: The Alakir Çay unit, Antalya Complex, southwest Turkey. In: Raymond, L.A. (Ed.), Melanges: Their nature, origin, and significance. Geological Society of America Special Paper 198, p. 139-152. 


\section{Figures captions}

Table 1 - Characteristic feautures of the two end members of olistostromes, based on the nature of blocks and mechanism of formation.

Figure 1 - Global distribution of main modern (from Mienert et al., 2003) and ancient (from Raymond, 1984; Camerlenghi and Pini, 2009; Festa et al., 2010a) olistostromes and submarine landslide deposits (modified after Dilek et al., 2012).

Figure 2 - Distribution of olistostromes and MTDs in the (A) Circum-Mediterranean Region (modified from Camerlenghi and Pini, 2009), (B) Appalachian orogenic belt (modified from Rast and Horton, 1989; Festa et al., 2010a; Codegone et al., 2012a), and (C) Western coast of the USA and Canada (from Aalto, 2014; Cowan, 1985; Raymond and Terranova, 1984; Brandon, 1989; Blome and Nestell, 1991; Raymond and Bero, 2015; Wakabayashi, 2015), distinguished by the tectonic setting of their formation and emplacement age. Tectonic lineaments in (A) from Camerlenghi and Pini (2009), Vezzani et al. (2010) and Quintana et al. (2015), in (B) from Hibbard et al. (2006) and Hatcher et al. (2007), in (C) from Wheeler and McFeely (1991) and Reed et al. (2005). BBF: Bloody Bluff Fault, BVBL: Baie Verte - Brompton Line, CBF: Chedabucto Fault, CF: Caledonia Fault, CPSZ: Central Piedmont Shear Zone, DHF: Dover - Hermitage Bay Fault, HLPVFS: Hollins Line - Pleasant Valley Fault System, LL: Logane Line, RIL: Red Indian Line.

Table 2 - Subdivision and classification of olistostromes (modified after Festa et al., 2010a, 2012b).

Figure 3- Conceptual models for the formation and emplacement mechanisms of olistostromes and ancient MTDs associated with various stages of rift-drift and passive margin evolution: (A) Intraoceanic settings, close to sea-floor spreading ridge (modified from Balestro et al., 2015b, Festa et al., 
2015a); (B) Passive margin at ocean-continent transition (OCT) (modified from Prior et al., 1984), and

(C) Collapse of a carbonate platform (modified from Bosellini, 1998). (D) Olistostrome sites depicted in 1894 10

the three conceptual models in A through C (from Balestro et al., 2015b). Field examples showing:(E) rounded to angular clasts of ultramafic rocks in a fine-to medium grained matrix of the same composition, derived from downslope mass-transport processes in intra-oceanic settings (Ligurian Units, Northern Apennines, Italy); (F) clast-supported debris flow consisting of polymictic rounded to angular clasts of ultrabasic rocks and an oceanic cover succession (Ligurian Units, Northern Apennines, Italy; courtesy of E. Barbero); (G) Muddy debris flow body (olistostrome) of the Modino basal complex (Northern Apennines, Italy; courtesy of C.C. Lucente), showing the flow-related deformational features of non-consolidated carbonate clasts in an argillaceous matrix; $(\mathbf{H})$ Tens of meters thick, channelized megabreccias, composed of platform blocks within a white-colored, hemipelagic Upper Cretaceous calcilutite (Majella Mountain, Central Apennines, Italy; see Festa et al., 2014a); (I) Upper Cretaceous megabreccia of calcareous limestone (Muttekopf, Calcareous Alps, Austria; see Ortner, 2001 and Amerman et al., 2009). The mountainside is about $300 \mathrm{~m}$ high; (L) Blocks (tens of meters in size) of white-colored platform carbonate (white arrows) in a dark, Ordovician shale matrix (Calingasta Valley, Argentina Precordillera). The mountainside is about 1000 m high.

Figure 4 - Conceptual model for the formation and emplacement of olistostromes and ancient MTDs associated with $(\mathbf{A})$ convergent margins and oceanic crust subduction (modified from von Huene et al., 1989; Festa et al., 2012b) and (B) collisional and (C) intra-collisional tectonic settings (modified from Festa et al. 2012b, 2015c). (D) Olistostrome sites depicted in the three conceptual models in A through C (from Marroni et al., 2010; Festa et al., 2013) and accretion of a lithospheric mantle (modified from Bortolotti et al., 2013). Field examples of olistostromes associated with convergent margin tectonics and oceanic crust subduction: (E) rounded to elongated blocks (deep-water limestone, silicified mudstone, and siltstone) included in a brecciated matrix (Berks County, Central 
Appalachians, Pennsylvania) formed by debris flow in front of the middle Ordovician accretionary wedge (see Lash, 1987; Codegone et al., 2012a); (F) Close-up of clast-supported breccia (Panoche Road, Franciscan Complex, California), with clasts of metavolcanic and metagraywacke rocks, 10

created by debris flows shed into a trench (see Wakabayashi, 2012); (G) Coastal exposure of the

Pahaoa olistostrome (Glendu Rocks, East Coast of New Zealand); (H) Overturned succession showing a large ophiolitic block (several hundreds of meters wide) embedded in a turbiditic sequence, (Upper Cretaceous Casanova Complex, Northern Apennines, Italy; courtesy of E. Mutti); (I) Debris flow deposit with blocks of an oceanic cover succession in a sheared, shaly matrix (Casanova Complex, Northern Apennines, Italy); it formed at the frontal toe of the Ligurian Accretionary Wedge (i.e., Alpine retro-wedge) in the Late Cretaceous. Field examples of olistostromes associated with collisional and intra-collisional tectonics: (L) Precursory olistostrome of the uppermost portion of the Oligocene Macigno Costiero Formation (Cinque Terre area, La Spezia, Northern Apennines, Italy); (M) Olistostromal carpet in front of the Bodon and Forcada Nappes showing large olistoliths inside the Carboniferous Porma mélange (Cantabrian Zone, North Spain; see Alonso et al., 2006, 2015); (N) Olistostromal carpet displaying a debris flow deposit emplaced in the footwall of the Taconic Allochthon and showing fabric elements of tectonic overprint. Exotic blocks show lenticular shapes produced by tectonic shearing (Hoosic River at Schaghticoke Gorge, eastern NY, Central Appalachians - USA); (O) Panoramic view of an epi-nappe olistostrome, emplaced within the late Oligocene-early Miocene wedge-top basin succession atop of the Ligurian Units (Northern Apennines, Italy; see Festa et al., 2015b, 2015c).

Figure 5 - (A) Comparative diagrams for the frequency of preservation of ancient olistostromes / MTDs and modern submarine landslides in passive and active (convergent) margins in the CircumMediterranean Region (data of modern examples from Urgeles and Camerlenghi, 2013). (B, C, D) Comparative diagrams for the frequency of preservation of olistostromes in passive and active 
(convergent) margins through time in the Circum-Mediterranean Region (B), Appalachians (C) and the 1944 West Coast of the USA and Canada (D).

Figure 6 - Conceptual stratigraphic logs summarizing different types of studied olistostromes and MTDs. The recurrent structural facies associations are numbered from the base to the top. These schematic representations refer to inferred depocenters, in which the entire vertical succession is likely preserved.

Figure 7 - Dynamic classification of mass transport deposits showing genetic and evolutionary relationships among various processes responsible for their formation (modified from Nisbet and Piper, 1998; Ogata et al., 2012b). Slide/slump and turbidity currents represent the end - members of such broad spectrum of geological processes. Blocky-flow deposits (Mutti et al., 2006), which are similar to debris-flow deposits, except for carrying over-sized slide blocks, represent a transitional type between slumps and debris-flow deposits.

Figure 8 - Logarithmic diagram of average thickness versus average width of submarine landslides, showing relative sizes of ancient (dashed blue line envelope) and modern (solid red line envelope) olistostromes, MTDs and MTCs. Modified from Woodcock et al. (1979), Macdonald et al. (1993), Lucente and Pini (2003), Ogata et al. (2014a).

Figure 9 - Logarithmic diagram of Height of fall to horizontal runout $(\mathrm{H} / \mathrm{L})$ ratio versus volume for modern examples of subaerial and submarine landslide types (modified from Hampton et al., 1996; De Blasio et al., 2006; Urgeles and Camerlenghi, 2013; Calves et al., 2015) and ancient submarine MTDs and olistostromes (based on extrapolation of field observations). Black and red lines show a power fit to ancient MTDs/olistostromes and debris flows data, respectively. Key to lettering: Ay: Upper Cretaceous Ajabacas MTC (Callot et al., 2008), Ca: Oligocene-Miocene Val Tiepido Canossa 
olistostrome (e.g., Festa et al., 2015c), CMC: Miocene Casaglia-Monte della Colonna MTC (Lucente and Pini, 2003), Fb: Paleocene Friuli Basin MTD Units (Tunis and Venturini, 1992; Ogata et al., 2014b), He: Eocene Hecho Group megaturbidites (Labaume, 1992; Ogata et al., 2012b), Ma: Miocene

Makran olistostrome (Burg et al., 2008), Mo: Miocene Modino MTC (Lucente and Pini, 2008), Nj:

Nataraja (Calves et al., 2015), Po: Carboniferous Porma mélange (Alonso et al., 2006, 2015), SU:

Oligocene Specchio Unit MTC (Ogata et al., 2012c), Vi: Permian MTCs in the Vischkuil Fm. (van der Merwe et al., 2009).

Figure $10-($ A) Simplified geological cross-section of the Makran accretionary complex (modified from Burg et al., 2008), showing the emplacement of a basin-scale olistostrome along the slope of the frontal wedge. Note that part of the olistostromal body is involved in post-depositional thrusting. (B-C) Conceptual cross-sections of accretionary (B) and erosive (C) margins (modified from Festa et al., 2015c) showing different paths of material flow (from Vannucchi et al., 2012) and inferred emplacement trajectories of old and contemporaneous olistostromes and MTDs along the slope of an accretionary wedge. (D) Upper Cretaceous olistostrome in the external Ligurian Units, flattened and slightly deformed by compaction and horizontal shortening and reverse faulting (Northern Apennines, Italy); (E) Strongly flattened clasts of debris flow deposits within an olistostromal carpet at the base of the Ligurian nappe and overlying the Macigno foredeep complex (Northern Apennines, Italy); (F) Large block of sheared basic metavolcanic rock ("greenstone" beneath hammer) and smaller phacoids of sandstone (e.g., beneath scale) in a sheared sandstone and mudrock matrix (Heaven's Beach mélange, Franciscan Complex, California; see Raymond and Bero, 2015). Hammer handle $32 \mathrm{~cm}$ in length as a scale (courtesy of L.A. Raymond).

Figure $11-($ A) Geological map of the Poetstenkill Gorge in the Northern Appalachians (Troy, NY; modified from Festa et al., 2012a). Polygenetic mélange formation in this area was associated with thrust faulting during the Taconic orogeny (Taconic Frontal Thrust). The "structurally ordered" block-in- 
matrix fabric (SE corner of the map) of this mélange formed due to mixing of blocks from debris flow deposits (olistostromes) and broken formations. (B) Close-up view of a debris flow deposit with rounded clasts in a fine-grained matrix; (C) Unconformable contact between the olistostrome and the 10

broken-formation; (D) Close-up view of the polygenetic mélange (hanging wall) formed by thrustingrelated mixing of broken formation and debris flow (olistostromes) deposits.

Figure 12 - Conceptual profile of downslope transformation of cohesive olistostromes. (A) Downslope evolution of a submarine landslide complex displaying distinct zones of mass transport-related deformation and deformation mechanisms (modified from Ogata et al., 2014a). Relatively thick, matrix-dominated portions and matrix-rich shear zones represent the products of such localized, enhanced progressive deformation (from extensional to compressional, and their combination), characterizing specific portions of the MTD. (B) Progressive evolution of different phases of a slide mass, involving various stages of acceleration to deposition, with emphasis on dynamic loadingrelated substrate erosion/bypass (modified from Ogata et al., 2014b). (C) Block diagram of an olistostromal body and its flow direction, showing simple shear deformation of clasts at its base (modified from Pini et al., 2012). Photographs of polished hand samples from the basal shear zone of olistostromes in the Northern Apennines (Italy): (D) Extensionally sheared layers show a planar anisotropy crosscut by low-angle extensional shear surface (R shear: white lines) (modified from Festa et al., 2013); (E) Superposition along an erosive surface (white arrows and dashed line) of a brecciated lenticular body onto extensionally sheared shaly layers (modified from Festa et al., 2013); (F) Contractional shear zone, showing the reorientation of elongated hard clasts to an S-C fabric (white dashed lines; modified from Festa et al., 2015c).

Figure 13 - Simplified cross-sections of ductile and brittle-ductile deformation fabrics and their kinematic indicators as discussed in the text. Field photographs depict some of the most representative examples of these structures. The cartoon with a velocity profile displays the main 
2021 internal subdivisions, facies associations, and mesoscale structures of an evolving slide body 5

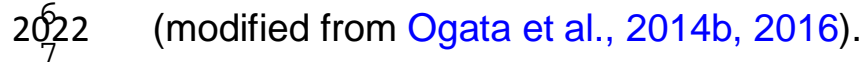

20323

Figure 14 - Correlation between main olistostromal events (cited in the text), tectonic settings, 2026 16 $\frac{17}{21027}$ 19 2028 orogenic stages and sea-level changes in the Circum-Mediterranean Region, Appalachians and Circum-Pacific Region (the West Coast of the USA and Canada, and the Andean Precordillera). Sealevel changes from Haq et al. (1987) for the Cenozoic, and Haq and Shutter (2008) and Snedden and 21 


\begin{tabular}{|c|c|c|c|c|c|c|}
\hline Products & Sub-Products & Nature of blocks & Mechanisms & $\begin{array}{c}\text { Lithological } \\
\text { unit } \\
\text { involved }\end{array}$ & $\begin{array}{l}\text { Contacts with host } \\
\text { rocks }\end{array}$ & Processes \\
\hline \multirow{2}{*}{ Olistostrome } & $\begin{array}{c}\text { Allolistostrome } \\
\text { Sedimentary mélange }\end{array}$ & Exotic and Native & Mixing & $\begin{array}{c}\text { Sedimentary } \\
\text { Metamorphic } \\
\text { Igneous } \\
\end{array}$ & \multirow{2}{*}{ Stratigraphic } & \multirow{2}{*}{$\begin{array}{l}\text { Sedimentary } \\
\text { (Mass } \\
\text { Transport) }\end{array}$} \\
\hline & $\begin{array}{c}\text { Endolistostrome } \\
\text { Sedimentary Broken } \\
\text { Formation }\end{array}$ & $\begin{array}{l}\text { Native (Intra- } \\
\text { formational) }\end{array}$ & $\begin{array}{c}\text { Stratal } \\
\text { disruption }\end{array}$ & Sedimentary & & \\
\hline
\end{tabular}

Table 1 - Festa et al. 
Click here to download high resolution image

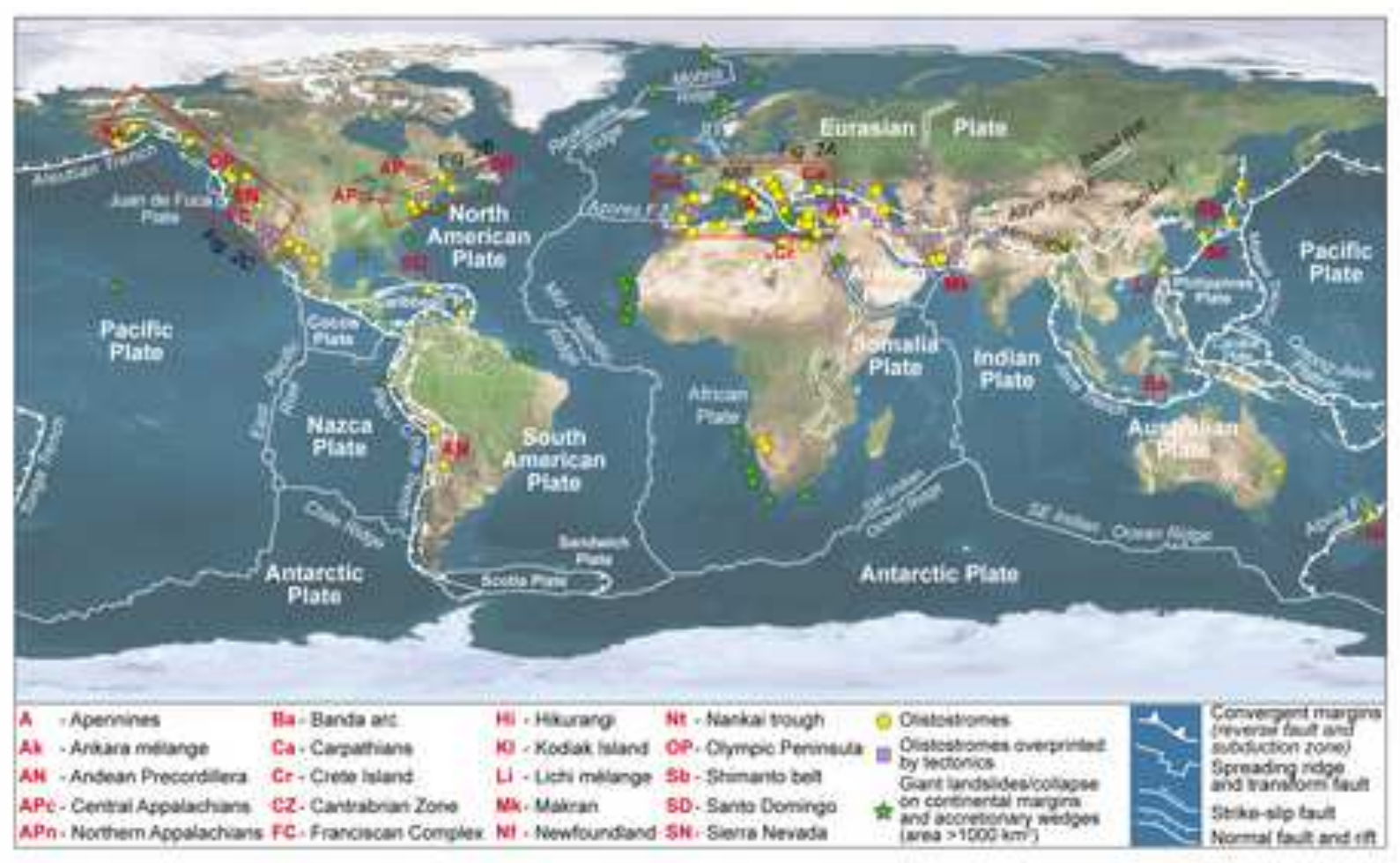

Figure 1 - Festa of al 
Figure 2

Click here to download high resolution image
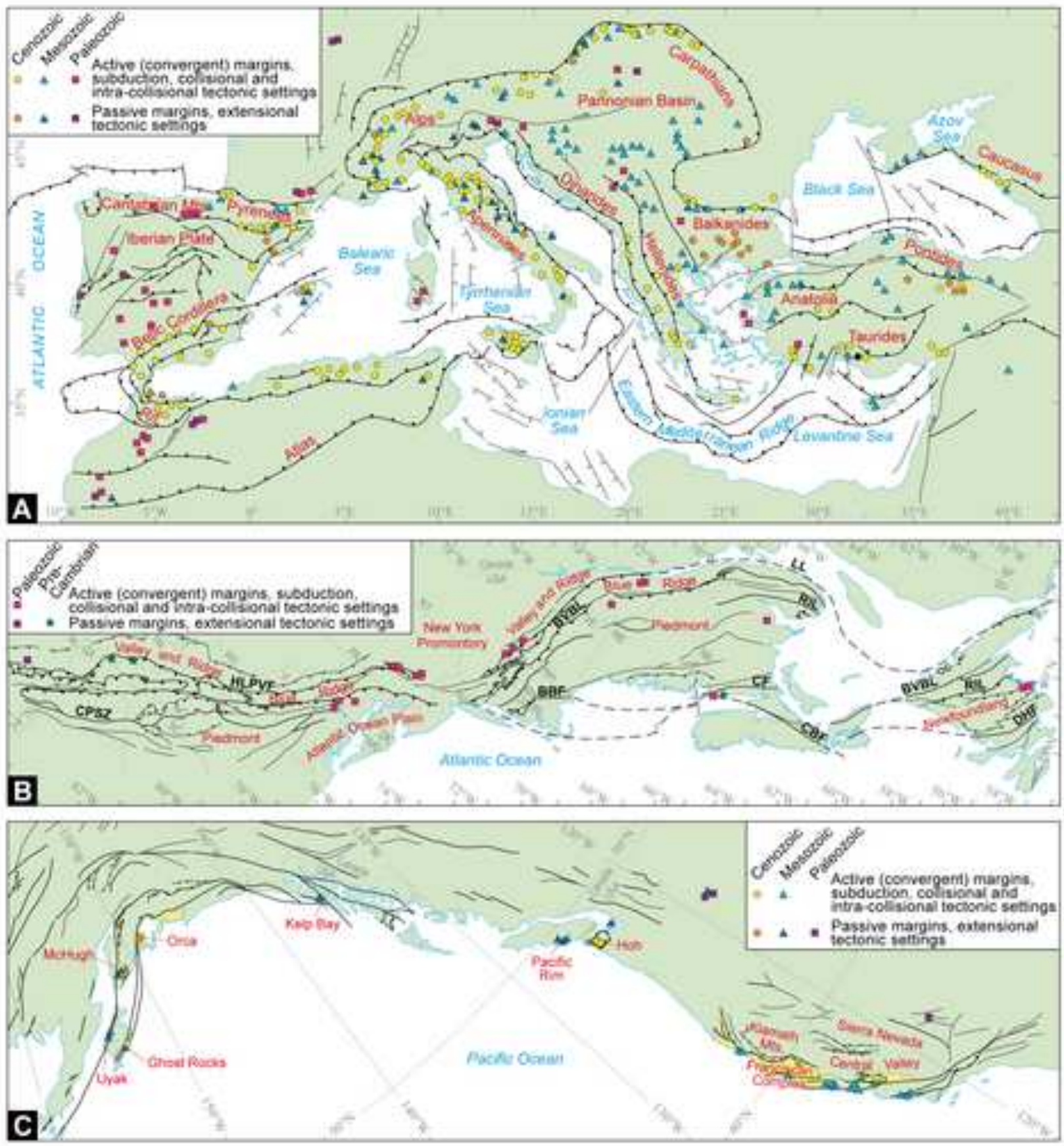

Figure 2, Festa et at 


\begin{tabular}{|c|c|c|c|c|c|}
\hline $\begin{array}{l}\text { Types of Olistostrome } \\
\text { related to: }\end{array}$ & $\begin{array}{l}\text { Geodynamic } \\
\text { environment }\end{array}$ & Processes & \begin{tabular}{|c|} 
Triggering \\
mechanisms
\end{tabular} & Products & Mesoscale characteristics \\
\hline \multirow{2}{*}{$\begin{array}{l}\text { Passive margin } \\
\begin{array}{l}\text { Collapse of platform } \\
\text { margins }\end{array} \\
\begin{array}{l}\text { Mass-transport } \\
\text { deposits at the ocean- } \\
\text { continent transition } \\
(\text { OCT })\end{array} \\
\end{array}$} & $\mid \begin{array}{c}\text { Passive margins } \\
\text { (during and } \\
\text { after rifting) }\end{array}$ & $\begin{array}{l}\text { MTP (debris avalanches } \\
\text { and flows, etc.) }\end{array}$ & Tectonic & $\begin{array}{l}\text { MTD (megabreccias, } \\
\text { breccias, olistolith fields, } \\
\text { debrites, slide blocks, etc.) }\end{array}$ & $\begin{array}{c}\text { Chaotic angular clasts (cm to } \\
>10 \text { m) in fine-grained } \\
\text { (pelitic) matrix }\end{array}$ \\
\hline & $\begin{array}{c}\text { Ocean-continent } \\
\text { transition }\end{array}$ & $\begin{array}{c}\text { SSD and MTP with related } \\
\text { progressive deformation } \\
\text { from slumping to debris } \\
\text { flows, to gravitational } \\
\text { sliding }\end{array}$ & \begin{tabular}{|c|} 
Tectonic, \\
sedimentary
\end{tabular} & $\begin{array}{c}\text { MTD, olistostromes with } \\
\text { continent rock olistoliths } \\
\text { (tens of meters to several } \\
\mathrm{km} \text { slide blocks) in a matrix } \\
\text { of oceanic origin }\end{array}$ & $\begin{array}{c}\text { Chaotic monomictic to } \\
\text { polymictic brecciated } \\
\text { (matrix-supported) masses } \\
\text { (including native, extra- } \\
\text { basinal and/or exotic blocks) }\end{array}$ \\
\hline $\begin{array}{l}\text { Intra-oceanic } \\
\text { downslope mass- } \\
\text { transport deposits }\end{array}$ & $\begin{array}{l}\text { Oceanic realm } \\
\text { (mid-oceanic } \\
\text { ridge, } \\
\text { seamounts) }\end{array}$ & $\begin{array}{l}\text { MTP (debris avalanches } \\
\text { and flows, etc.) }\end{array}$ & Tectonic & $\begin{array}{l}\text { MTD (breccias, olistolith } \\
\text { fields, debrites, slide } \\
\text { blocks, etc.) }\end{array}$ & $\begin{array}{c}\text { Chaotic angular clasts (cm to } \\
>5 \mathrm{~m} \text { ) in fine-grained pelagic } \\
\text { matrix }\end{array}$ \\
\hline \multirow[t]{2}{*}{$\begin{array}{l}\text { Convergent margins and } \\
\text { oceanic crust subduction } \\
\text { Mass-transport } \\
\text { deposits at the wedge } \\
\text { and retro-wedge front }\end{array}$} & $\begin{array}{c}\text { Subduction } \\
\text { (at the front of } \\
\text { the wedge) and } \\
\text { fore-arc basins }\end{array}$ & \multirow{2}{*}{\begin{tabular}{|} 
MTP (debris flows and \\
avalanches, slumps, slides, \\
etc.)
\end{tabular}} & \multirow{2}{*}{$\begin{array}{c}\text { Tectonic, } \\
\text { sedimentary }\end{array}$} & $\begin{array}{l}\text { MTD, BrFm, olistostromes } \\
\text { (olistoliths, olistolith fields } \\
\text { and swarm, slide blocks) }\end{array}$ & \multirow{2}{*}{$\begin{array}{l}\text { Chaotic BIM fabric } \\
\text { (including native, } \\
\text { extra-basinal and/or } \\
\text { exotic blocks) }\end{array}$} \\
\hline & 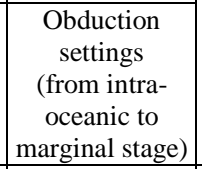 & & & $\begin{array}{l}\text { MTD, BrFm, olistostromes } \\
\text { (olistoliths, olistolith fields, } \\
\text { slide blocks, breccias, } \\
\text { debrites) }\end{array}$ & \\
\hline 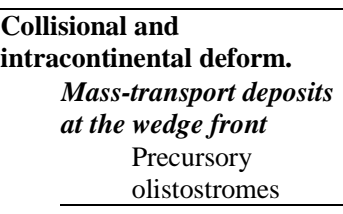 & \multirow{2}{*}{$\begin{array}{l}\text { At the base or at } \\
\text { the front of } \\
\text { intra-continental } \\
\text { thrust sheets or } \\
\text { nappes }\end{array}$} & $\begin{array}{c}\text { MTP (debris flows and } \\
\text { avalanches, slumps, slides, } \\
\text { etc.) }\end{array}$ & $\begin{array}{c}\text { Tectonic, } \\
\text { sedimentary }\end{array}$ & $\begin{array}{l}\text { MTD, olistostromes } \\
\text { (olistoliths, olistolith fields } \\
\text { and swarm, slide blocks) }\end{array}$ & $\begin{array}{c}\text { Chaotic BIM fabric (from } \\
\text { matrix-supported } \mathrm{cm} \text {-to } \mathrm{m} \text { in } \\
\text { size blocks to clast supported } \\
>10 \mathrm{~m} \text { blocks and olistoliths) }\end{array}$ \\
\hline $\begin{array}{l}\text { Olistostromal } \\
\text { carpet }\end{array}$ & & $\begin{array}{l}\text { TSD: fault-to fold-related, } \\
\text { fluidification (overprinting } \\
\text { previous mass-wasting- } \\
\text { related deformation) } \\
\end{array}$ & $\begin{array}{c}\text { Tectonic, } \\
\text { sedimentary }\end{array}$ & \begin{tabular}{|c|} 
Mélanges (exotic blocks \\
being commonly recycled \\
from other previously \\
formed olistostromes) \\
\end{tabular} & $\begin{array}{l}\text { Chaotic BIM fabric } \\
\text { overprinted by tectonic } \\
\text { deformation and shearing }\end{array}$ \\
\hline $\begin{array}{l}\text { Intra-nappe } \\
\text { Sedimentary }\end{array}$ & \multirow{2}{*}{$\begin{array}{l}\text { Within intra- } \\
\text { continental } \\
\text { thrust sheets or } \\
\text { nappes }\end{array}$} & $\begin{array}{c}\text { MTP (debris flows and } \\
\text { avalanches, slumps, slides, } \\
\text { etc.) }\end{array}$ & $\begin{array}{c}\text { Tectonic, } \\
\text { sedimentary }\end{array}$ & $\begin{array}{l}\text { MTD, olistostromes } \\
\text { (olistoliths, olistolith fields } \\
\text { and swarm, slide blocks) }\end{array}$ & $\begin{array}{c}\text { Chaotic BIM fabric (blocks } \\
\text { of intra-basinal origin) }\end{array}$ \\
\hline $\begin{array}{l}\text { Tectono- } \\
\text { sedimentary }\end{array}$ & & \begin{tabular}{|c|} 
TSD: fault-to fold-related, \\
fluidification (overprinting \\
previous mass-wasting- \\
related deformation)
\end{tabular} & Tectonic & $\begin{array}{l}\text { BrFm; mélanges (exotic } \\
\text { blocks being commonly } \\
\text { recycled from other } \\
\text { previously formed } \\
\text { olistostromes) }\end{array}$ & $\begin{array}{l}\text { Structurally ordered BIM } \\
\text { fabric (parallel orientation of } \\
\text { blocks and matrix features - } \\
\text { i.e. pseudo-bedding) }\end{array}$ \\
\hline Epi-nappe & \multirow{2}{*}{\begin{tabular}{|l|} 
A top of intra- \\
continental \\
thrust sheets \\
or nappes \\
(e.g. piggy back, \\
top thrust \\
basins)
\end{tabular}} & $\begin{array}{c}\text { MTP (debris flows and } \\
\text { avalanches, slumps, slides, } \\
\text { etc.) }\end{array}$ & $\begin{array}{c}\text { Tectonic, } \\
\text { sedimentary }\end{array}$ & $\begin{array}{l}\text { MTD, olistostromes } \\
\text { (olistoliths, olistolith fields } \\
\text { and swarm, slide blocks) }\end{array}$ & $\begin{array}{l}\text { Chaotic BIM fabric } \\
\text { (originated from the } \\
\text { succession tectonically } \\
\text { imbricated in the thrust- } \\
\text { sheet) }\end{array}$ \\
\hline $\begin{array}{l}\text { Tectono- } \\
\text { sedimentary }\end{array}$ & & $\begin{array}{l}\text { TSD (overprinting } \\
\text { previous mass-wasting- } \\
\text { related deformation) }\end{array}$ & $\begin{array}{c}\text { Tectonic, } \\
\text { sedimentary }\end{array}$ & $\begin{array}{l}\text { BrFm; mélanges (exotic } \\
\text { blocks being commonly } \\
\text { recycled from other } \\
\text { previously formed } \\
\text { olistostromes) }\end{array}$ & $\begin{array}{l}\text { Structurally ordered BIM } \\
\text { fabric }\end{array}$ \\
\hline \multicolumn{2}{|c|}{$\begin{array}{l}\text { BIM - Block-in-matrix } \\
\text { BrFm - Sedimentary Broken Formation }\end{array}$} & \multicolumn{2}{|c|}{$\begin{array}{l}\text { MTD - Mass-transport deposits } \\
\text { MTP - Mass-transport processes }\end{array}$} & \multicolumn{2}{|c|}{$\begin{array}{l}\text { SSD - Soft sediment deformation } \\
\text { TSD - Tectonic stratal disruption }\end{array}$} \\
\hline
\end{tabular}

Table 2 - Festa et al._R1 
Click here to download high resolution image
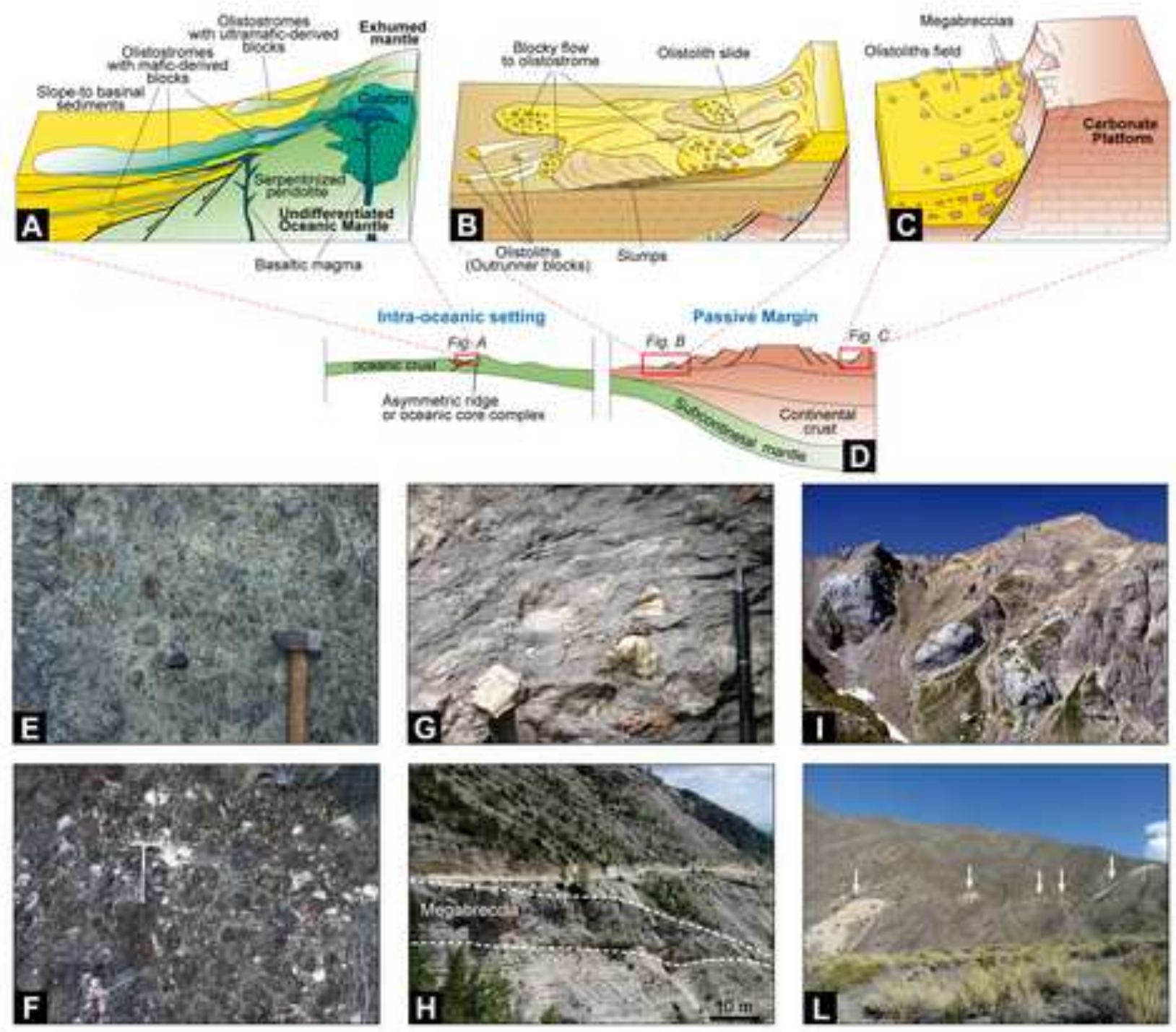

Figure 3. Festa ef at. 
Click here to download high resolution image
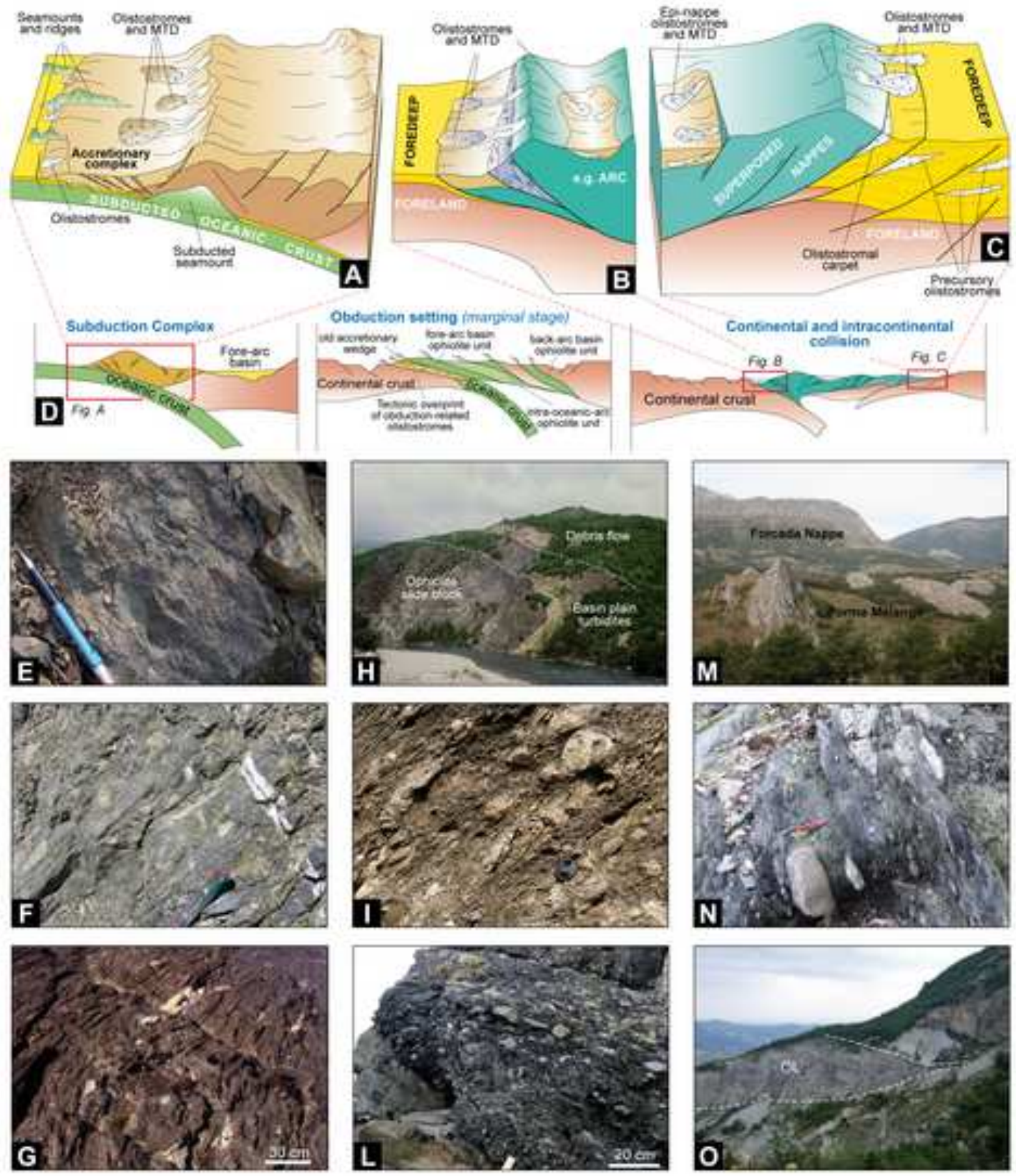

Figuro 4 - Festa et al Rs 
Click here to download high resolution image
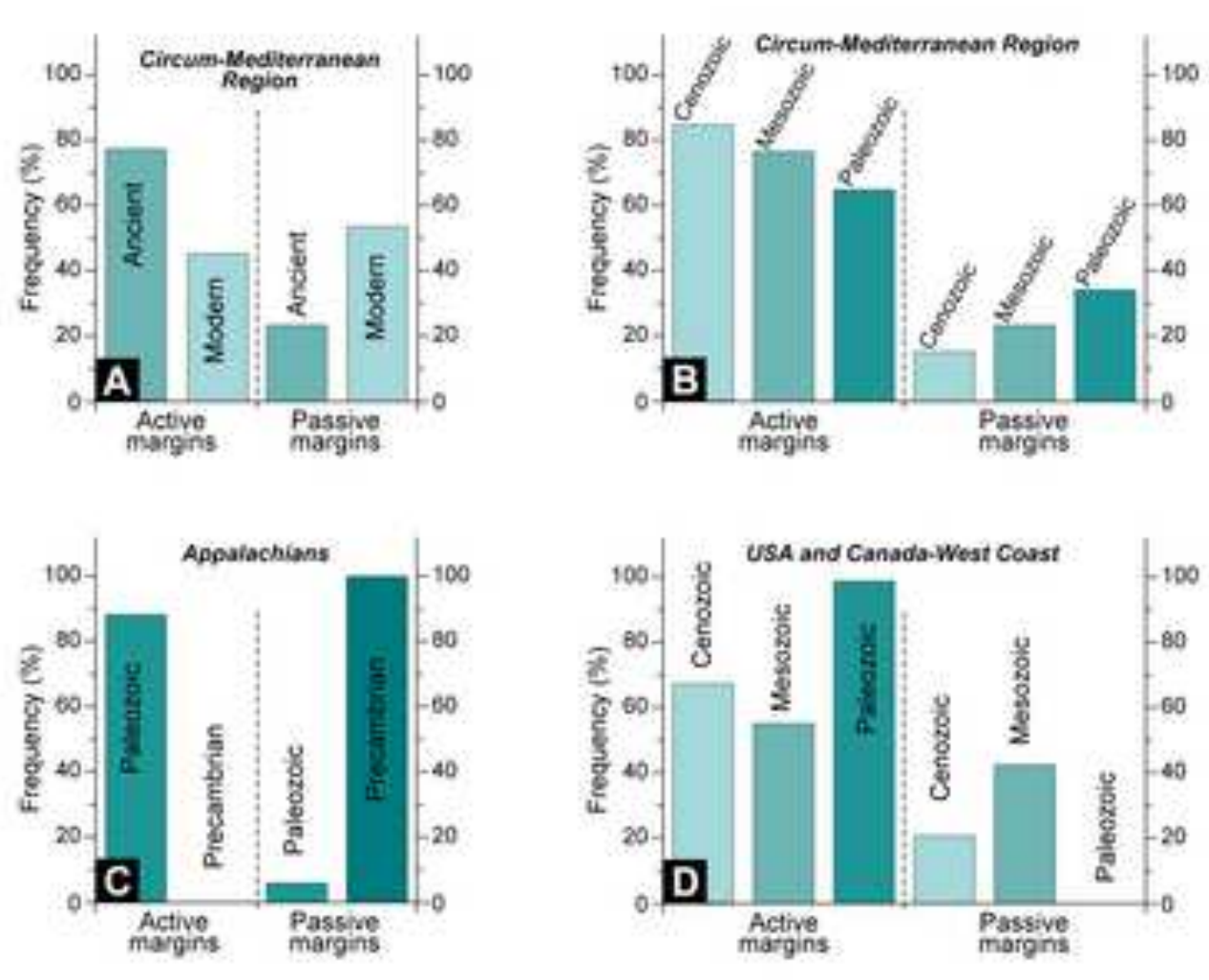

Figure 5 - Festa et al. 
Figure 6
Click here to download high resolution image

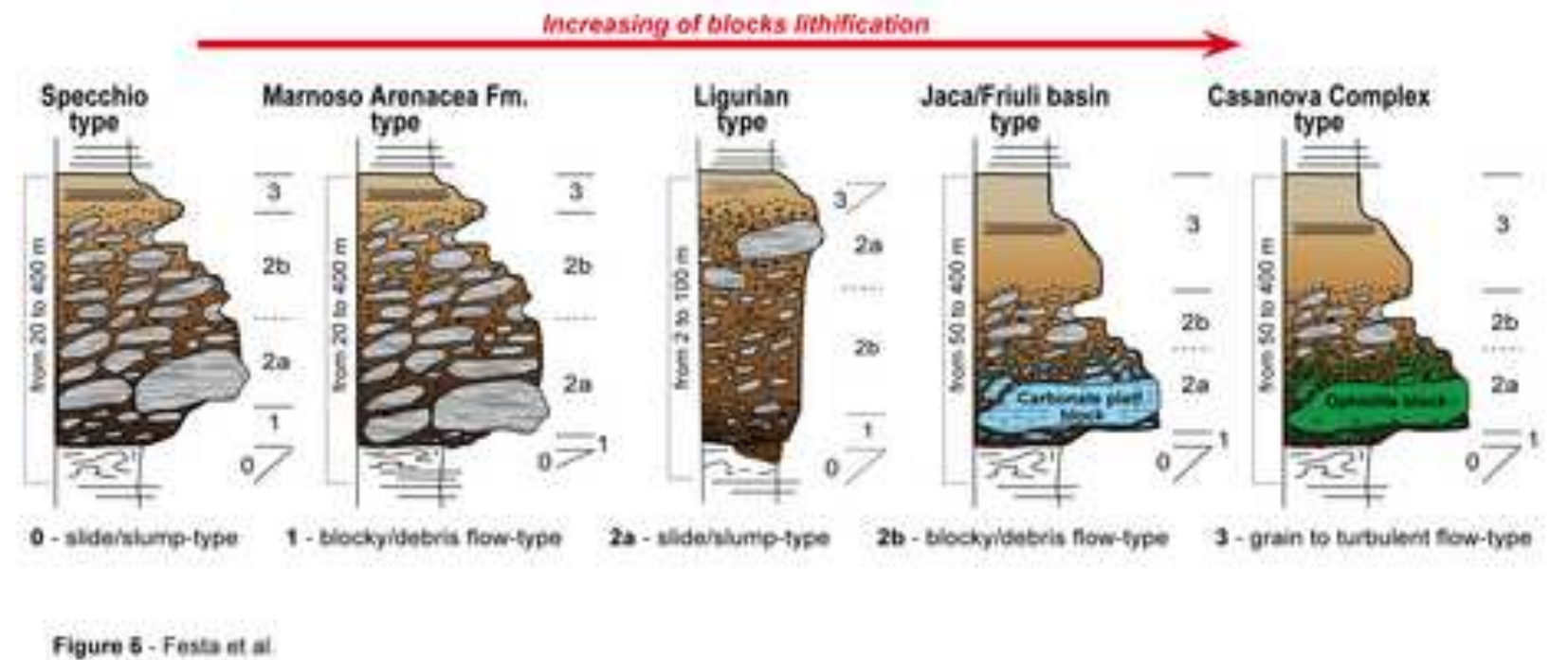

Figure 6
Click here to download high re

(1) atg- blockylobris now-ype $\quad 3$-grain to burbulent fow-bype

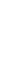

creasing of blocks fichification

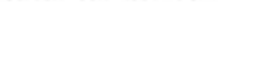

$\sqrt{2}$

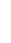

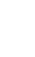


Figure 7

Click here to download high resolution image

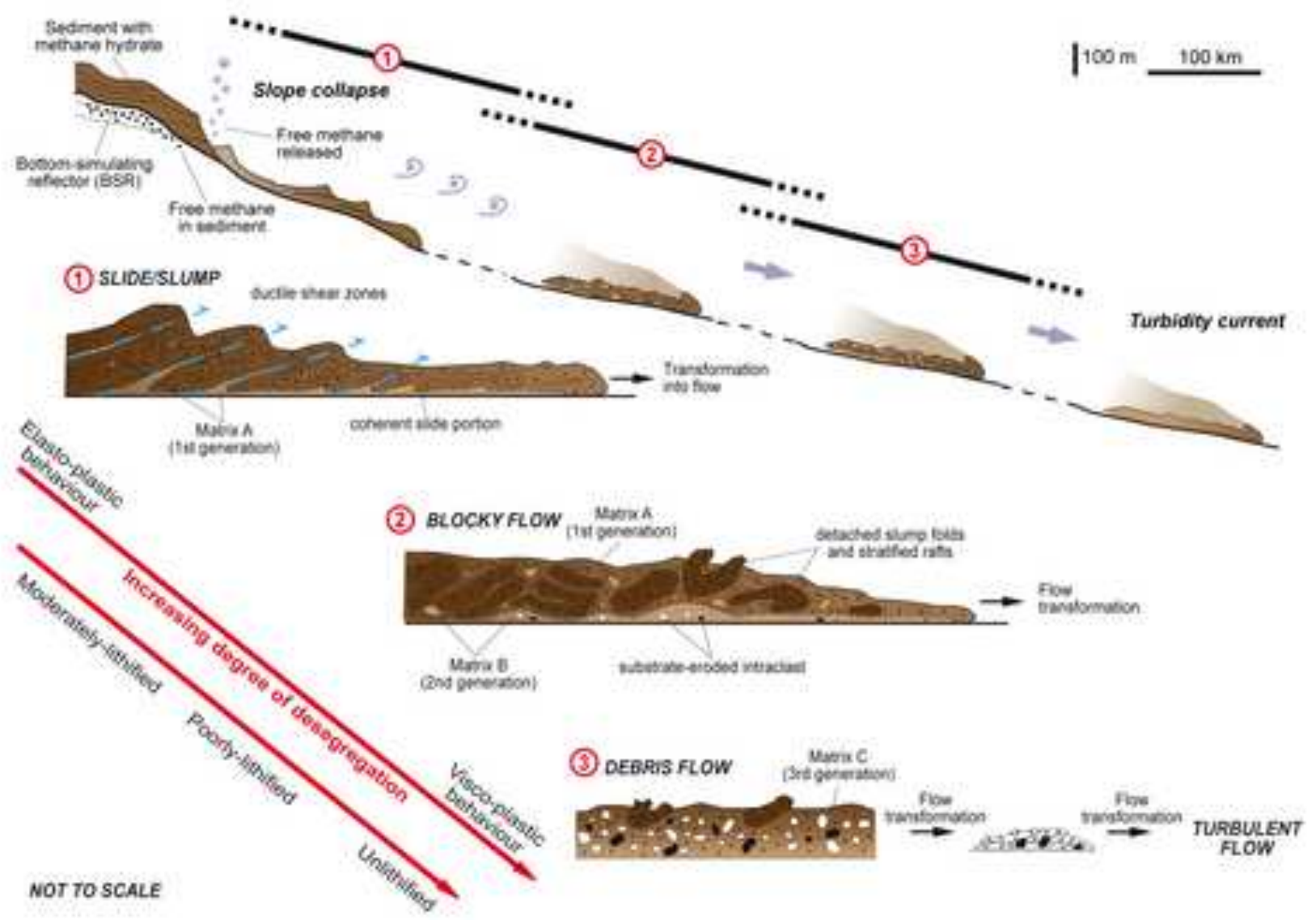

Figure 7 - Fenta et at 


\section{Click here to download high resolution image}

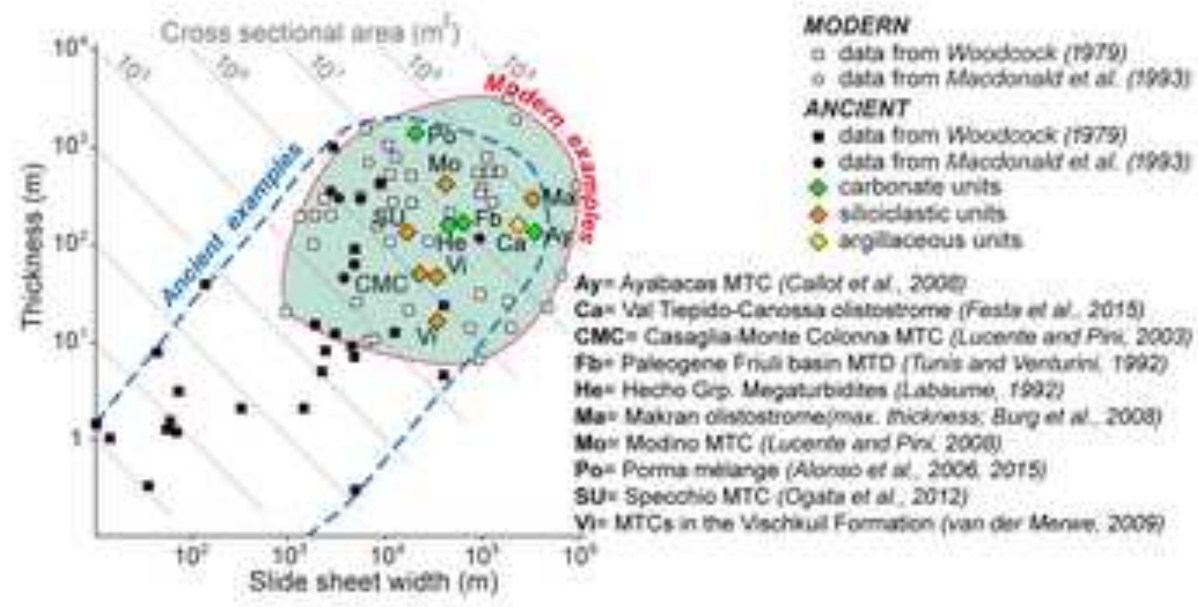

Figure a - Festa et al 
Click here to download high resolution image

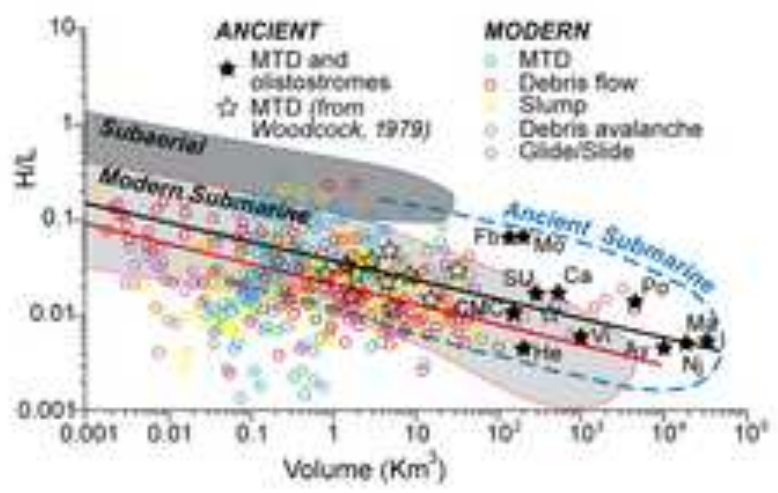

Figure 9. Fessa et al 
Click here to download high resolution image
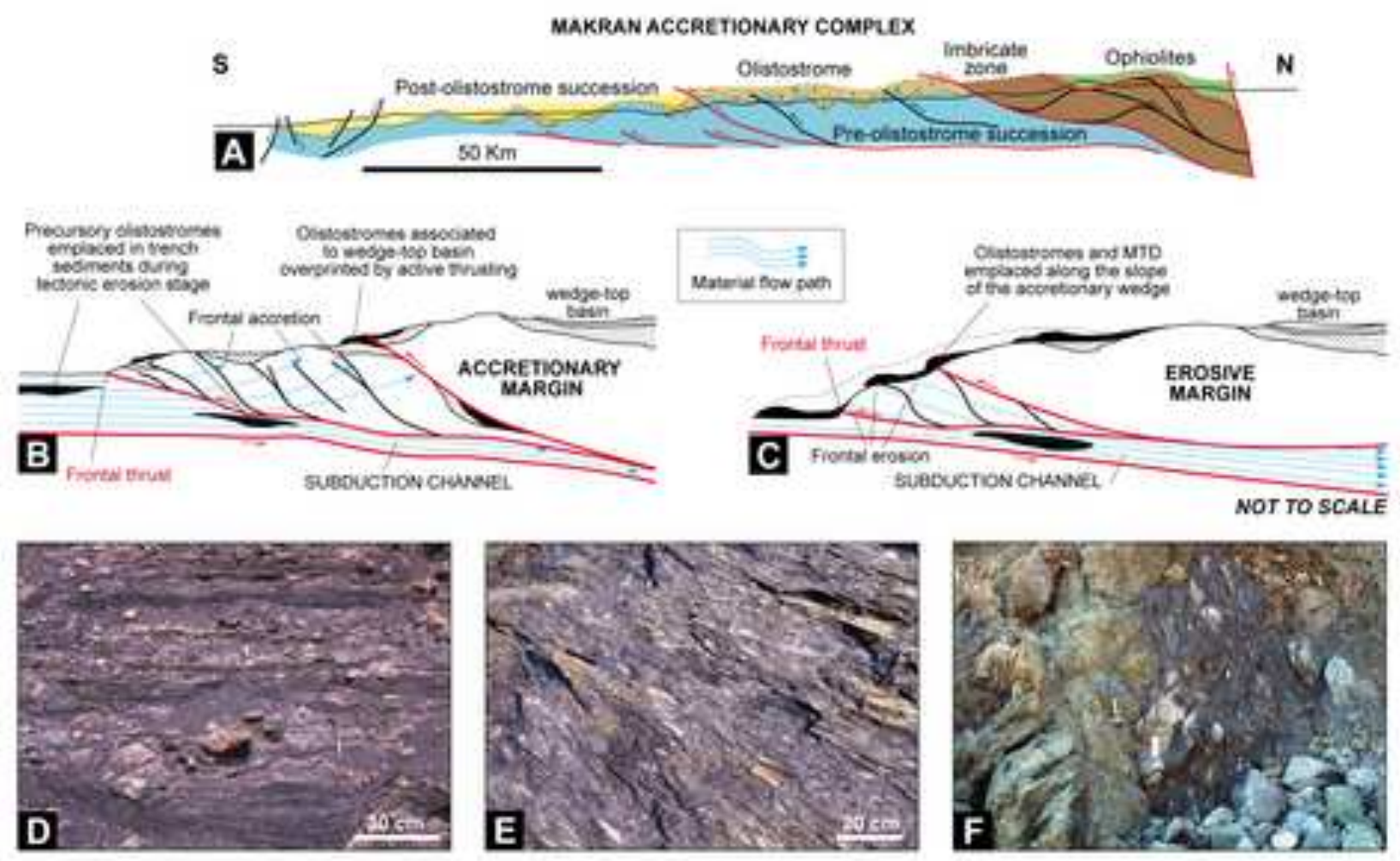

Figuee 10 - Festa et al 


\section{Figure 11}

Click here to download high resolution image
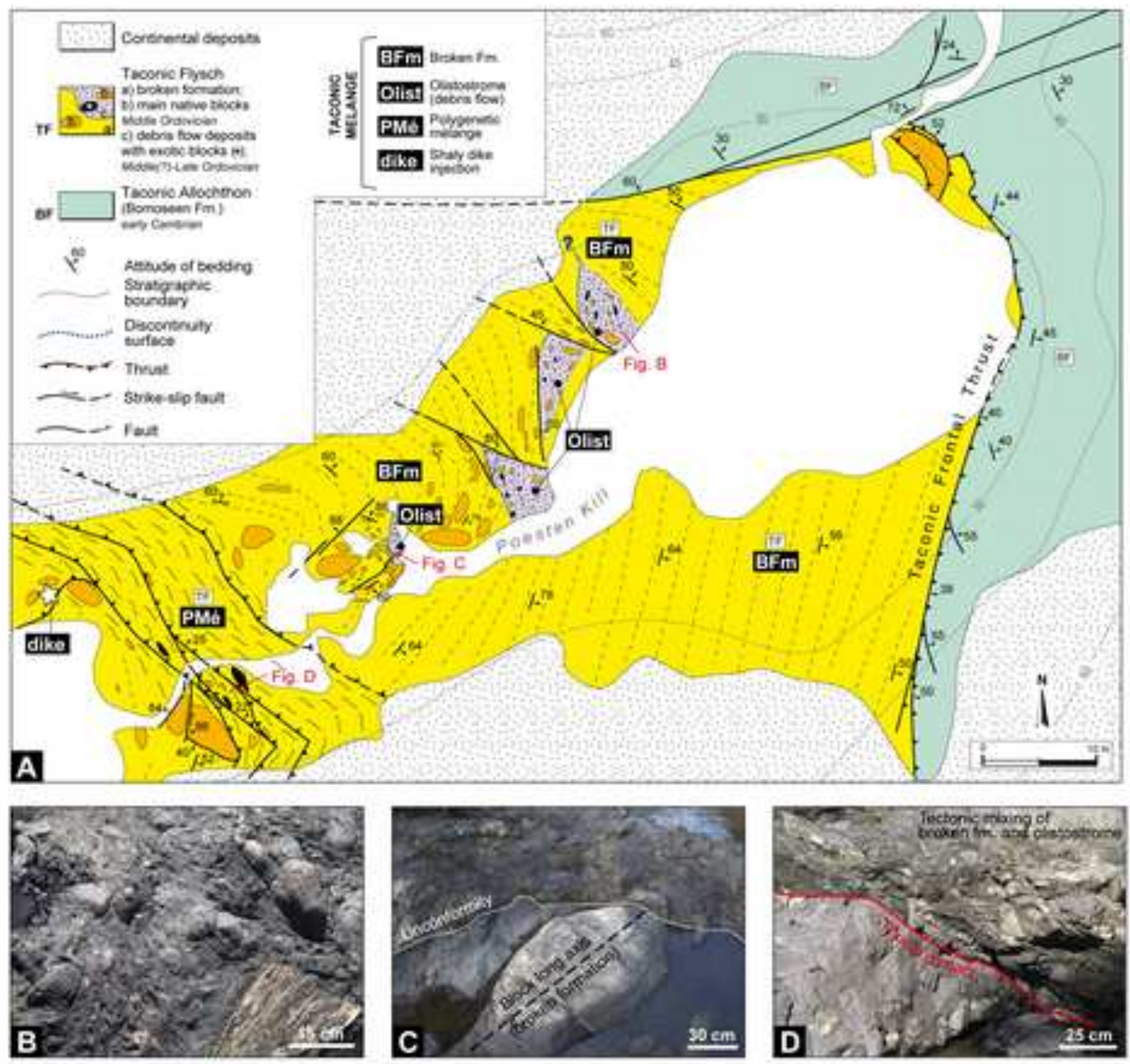

Figume 11 - Festa of $\alpha$ 
Click here to download high resolution image
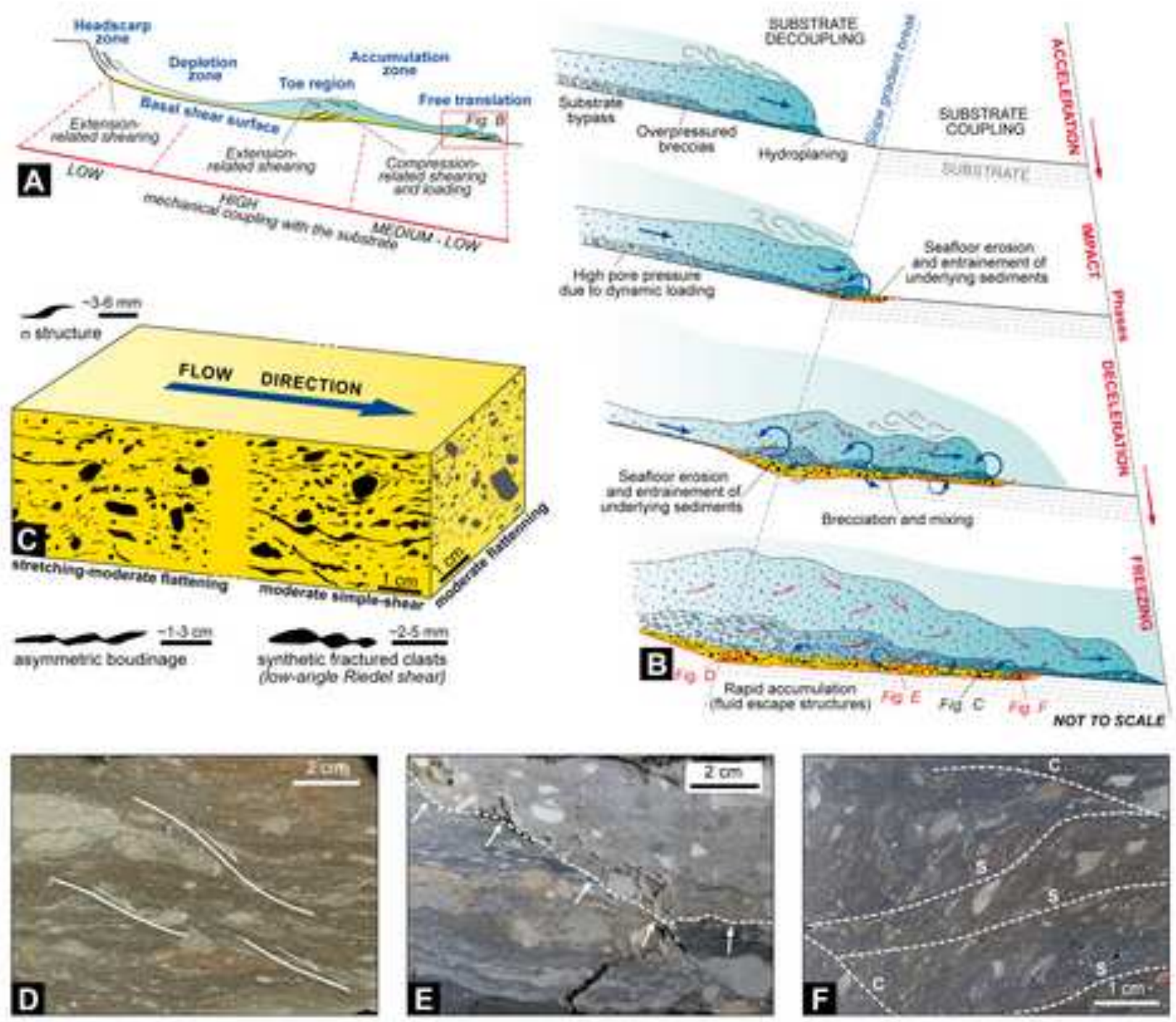

Figure 12 - Festa it at 
Click here to download high resolution image
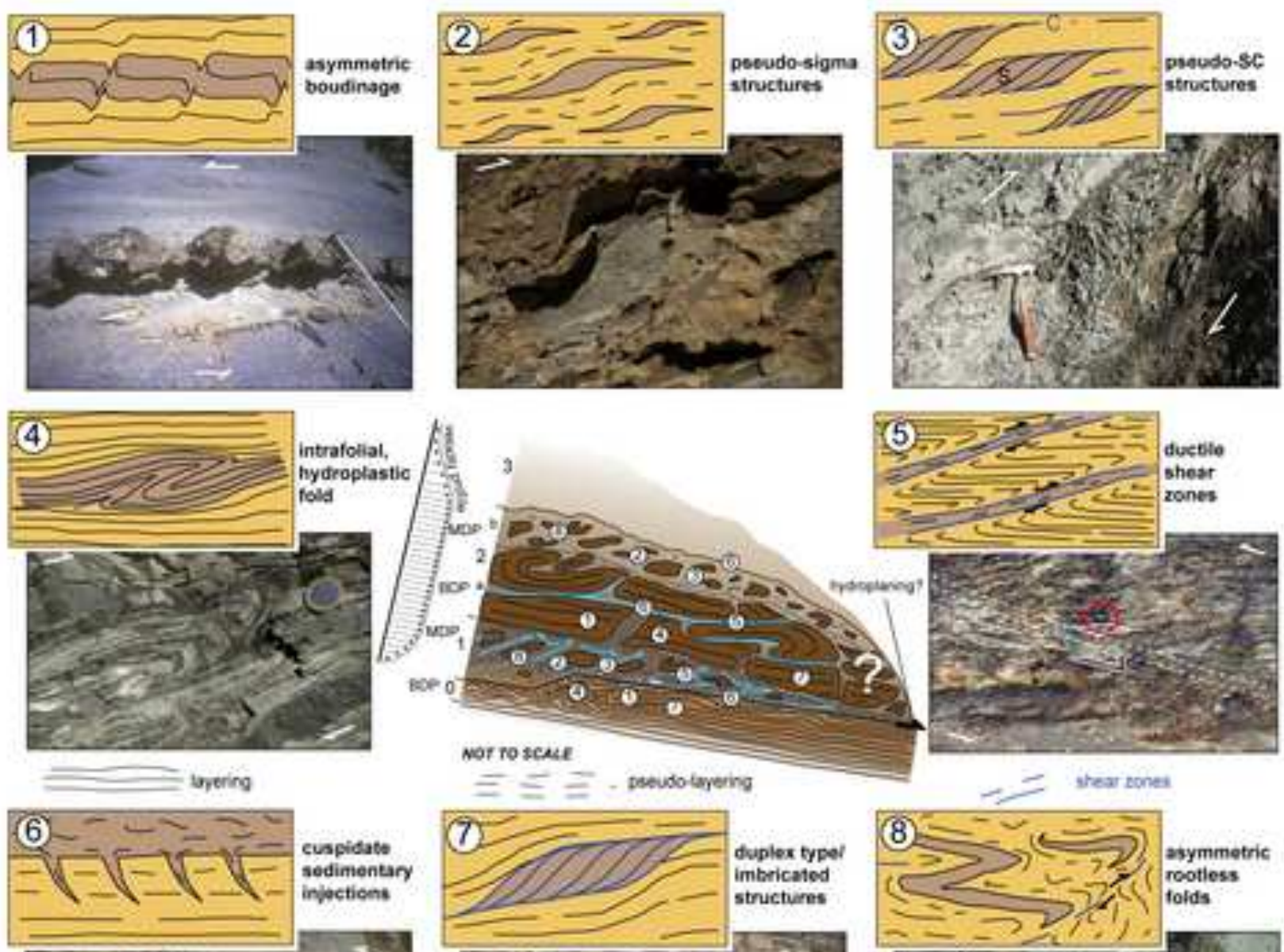

$$
\text { I } \equiv \text { - pesudotwering }
$$
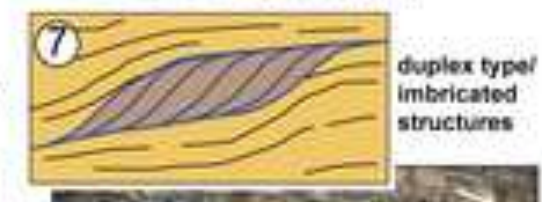
imbricated structures
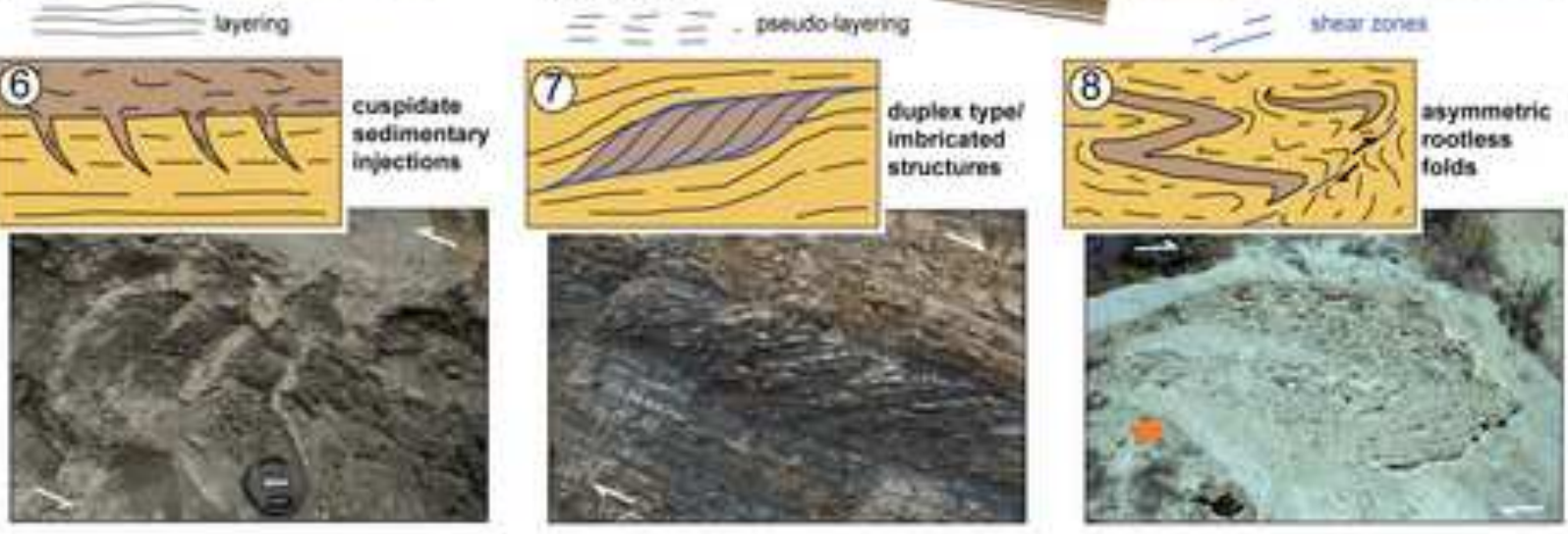

Figure 13 - Festa et at 
Figure 14

Click here to download high resolution image

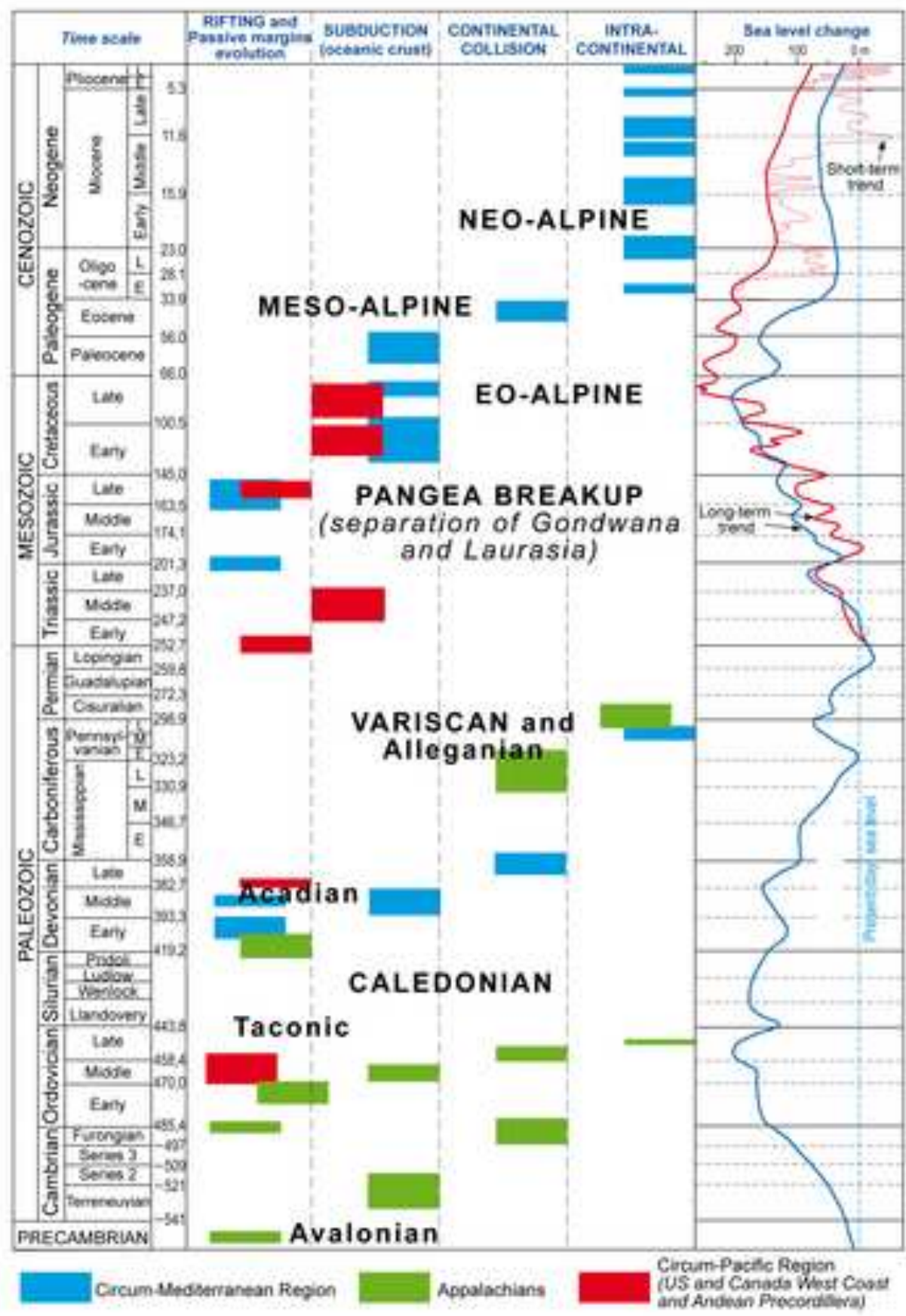

Figure 14-Festa et al 


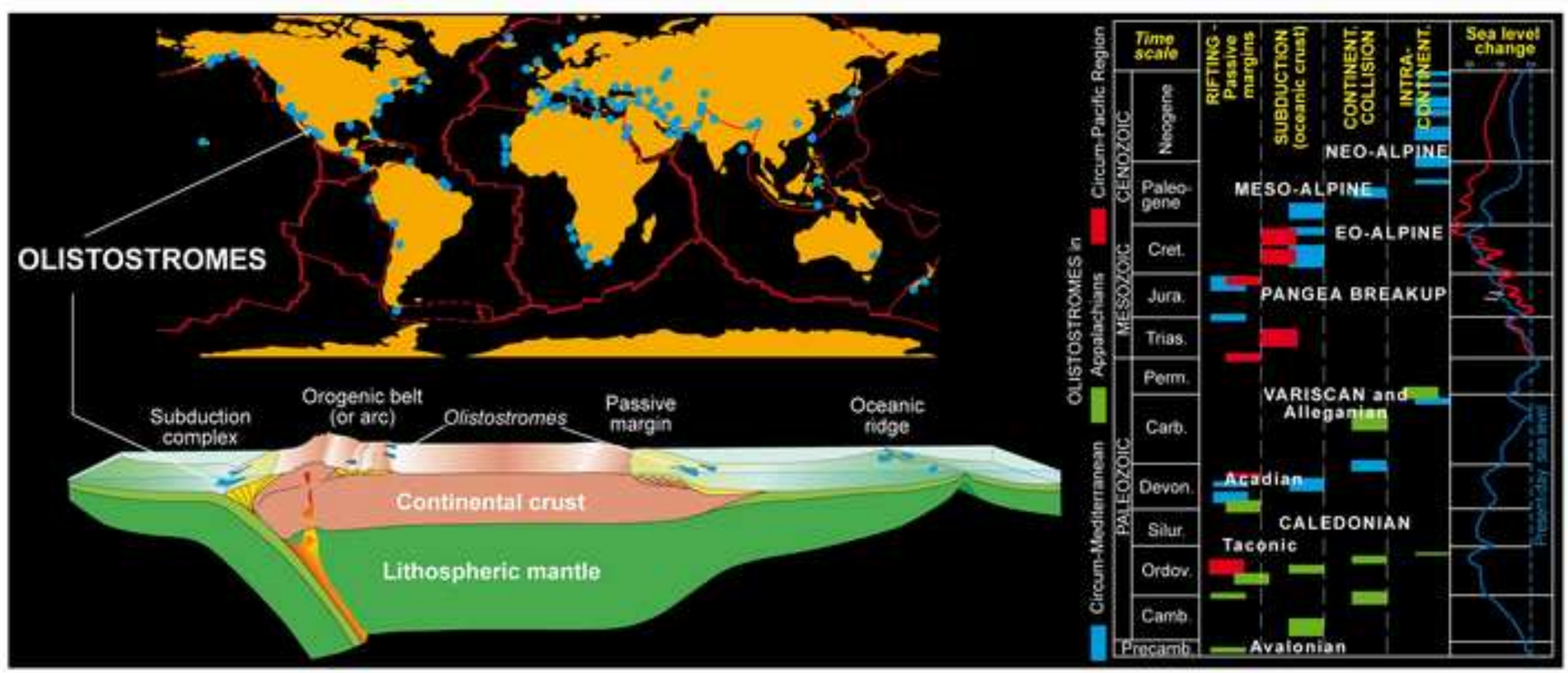

